\title{
WHAT IF WELFARE HAD NO WORK REQUIREMENTS? \\ THE AGE OF YOUNGEST CHILD EXEMPTION \\ AND THE RISE IN EMPLOYMENT OF SINGLE MOTHERS
}

\author{
JONATHAN F. PINGLE*
}

August, 2003

The Personal Responsibility and Work Opportunity Reconciliation Act of 1996 required states to increase welfare recipient employment and participation in welfare-to-work programs. These work requirements are sometimes credited for bringing about large employment increases among single mothers. However, this paper finds that employment among single mothers who were exempted from work requirements because they had young children rose as much as that of other single mothers. The results imply that the employment gains among single mothers in the late 1990s were due to economic growth and other policy changes rather than to the work requirements.

Key words: TANF; AFDC; welfare reform; PRWORA; employment. JEL classification number: I38, J21

* Federal Reserve Board, Washington, D.C. 20551. Phone: 202-452-3816. E-mail: Jonathan.F.Pingle@frb.gov. Thanks to the Urban Institute and staff, in particular Gretchen Rowe for discussing policy collection and information. Thanks to Charlie Baum for providing information on the Family and Medical Leave Act, and Ron Oertel for state minimum wage information. Beneficial comments have come from Donna Gilleskie, David Guilkey, Carolyn Heinrich, Pamela Holcomb, Thomas Mroz, David Ribar, Dan Rosenbaum, Chris Ruhm, William Wascher, and in particular Wilbert van der Klaauw. The views expressed here are solely those of the author and do not necessarily represent those of the Federal Reserve Board or its staff. 


\section{INTRODUCTION}

Work requirements were the political centerpiece of the landmark 1996 welfare reform legislation. The Personal Responsibility and Work Opportunity Reconciliation Act of 1996 ushered in Temporary Assistance for Needy Families (TANF) to replace Aid to Families with Dependent Children (AFDC) as the nation's primary income maintenance program for the poor. Caseloads have dropped dramatically, from a peak of over 5 million nationwide in 1994 to 2.1 million in 2001. The national employment rate of the program's target group, single mothers, rose by $25 \%$ between 1993 and 1999. ${ }^{1}$ Not coincidentally, welfare reform has been lauded as a success. Currently, Congress is considering the first revisions of TANF, and the proposals mandate further increases in required work. ${ }^{2}$

The magnitude of the caseload and employment changes motivates a logical question for research: What caused these changes? TANF's work requirements are one popular explanation. This paper's quasi-experimental evaluation uses a category of recipients who are exempt from the requirements as a comparison group to test the link between work requirements and employment growth. In particular, states exempt women with children under a certain age, commonly 12 or 36 months, from work requirements. This analysis uses that group to pose the counterfactual - how would single mothers have behaved if everything else during the 1990s were the same, but there were no work requirements? The answer is that, from 1993, through the period of reform, until 1999, the employment of exempt single mothers increased as much as the employment of women subject to the new rules. The results show no effect on employment that can be attributed to exempting single mothers from TANF's welfare program work requirements.

The remainder of the paper is arranged into six sections. The next section details the related policies, and discusses the exemption, how it is applied, and understood. Section III briefly reviews the existing research. The fourth section reviews the data and variables. The fifth section discusses employment trends, the empirical strategy, relaxes many typical difference-indifferences assumptions, including allowing state policies and economic forces to affect the

1. Karoly [2001] and Grogger [2001]. See Blank and Schmidt [2001] for a detailed overview of the trends during the 1990s. According to the Bureau of Labor Statistics, the employment of over age 16 female family heads rose by 25\% between March of 1993 and March of 1999.

2. See H.R. 4737 of the $107^{\text {th }}$ Congress. Currently (as of Sept. 2, 2003) the latest revision (draft) of the legislation is H.R. 4 as presented to the $108^{\text {th }}$ Congress. Last action on the bill was Feb. 13 when it was referred to the Senate Committee on Finance. 
exempt and not-exempt differently, and then notes empirical results. Section VI concludes. Additional results are shown in the Appendix.

\section{POLICY BACKGROUND}

TANF was passed during a period of shrinking welfare rolls and strong employment growth among single mothers. Figure I shows the drop in national welfare caseloads of nearly 3 million families between 1994 and 2001. That same pattern is shown in Figure II, for a sample of single mothers with children age 10 or under from the Current Population Survey (CPS), the sample used in the analysis below. The percent of the single mothers who received welfare during the prior year fell from over $40 \%$ to nearly $15 \%$. Figure II also shows that at the same time, their employment rate rose by more than $30 \%$. The close correlation between caseloads and employment is highly suggestive of welfare reform's influence. Coupled with the fact that such a large fraction of single mothers were recipients in 1993-1994, welfare reforms are often credited for the increased work among single mothers as a group. The introduction of the initial bill to revise TANF, House Resolution 4737, cites the higher employment rates and income of single mothers as evidence of TANF's success. The latest proposal to revise TANF would increase the current $50 \%$ of state caseloads required to be in work activities to $70 \%$.

However, TANF was not the first attempt at work-related rules for welfare recipients. Throughout the 1980s and into the 1990s, AFDC's work disincentives were becoming increasingly unpopular. In many states, penalties for increased income made recipients' effective wages zero. ${ }^{3}$ To increase employment, the Family Support Act of 1988 established the Job Opportunity and Basic Skills (JOBS) program which required states to provide education, training, work experience activities, English as a second language, job search, and other related services to AFDC participants. Penalties, or sanctions, that eliminated part of a recipient's cash grant, enforced the assignments. By 1995, states were required to have $20 \%$ of their JOBS mandatory welfare recipients in work activities, for an average of 20 hours per week. Although some states did not meet this standard [HHS, 1997], some states were more aggressive, and received "waivers" from the federal government allowing program changes. By August of 1996, 46 states had received some type of waiver. Some were minor, or limited to small areas, but

3. See Blank, Card and Robins [1999] for a discussion of AFDC's implicit tax rates and state efforts to relax the steep penalty. 


\section{FIGURE I}

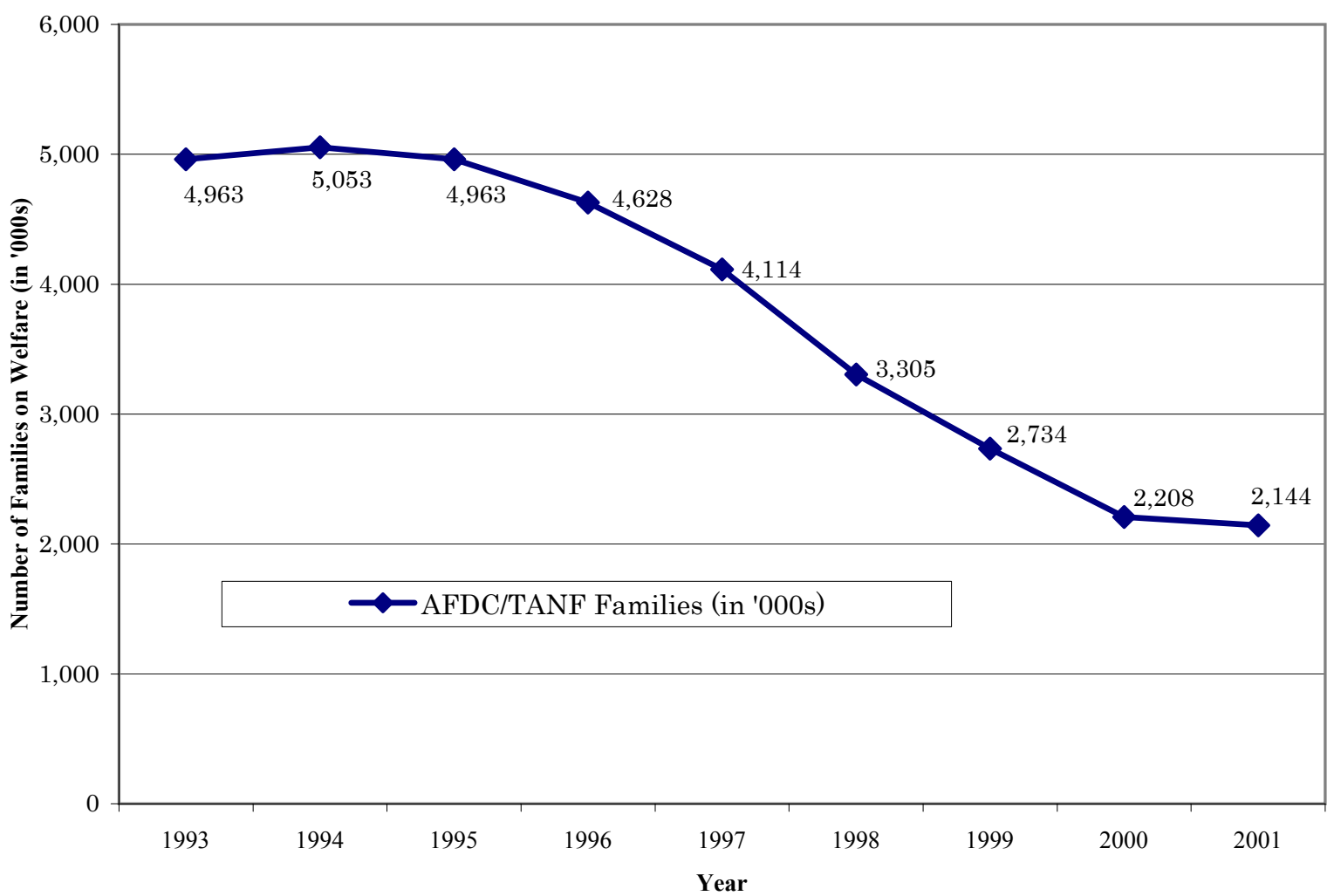

Figure I

Number of Families Collecting AFDC/TANF

(Source: U.S. Dept. of HHS) 
FIGURE II

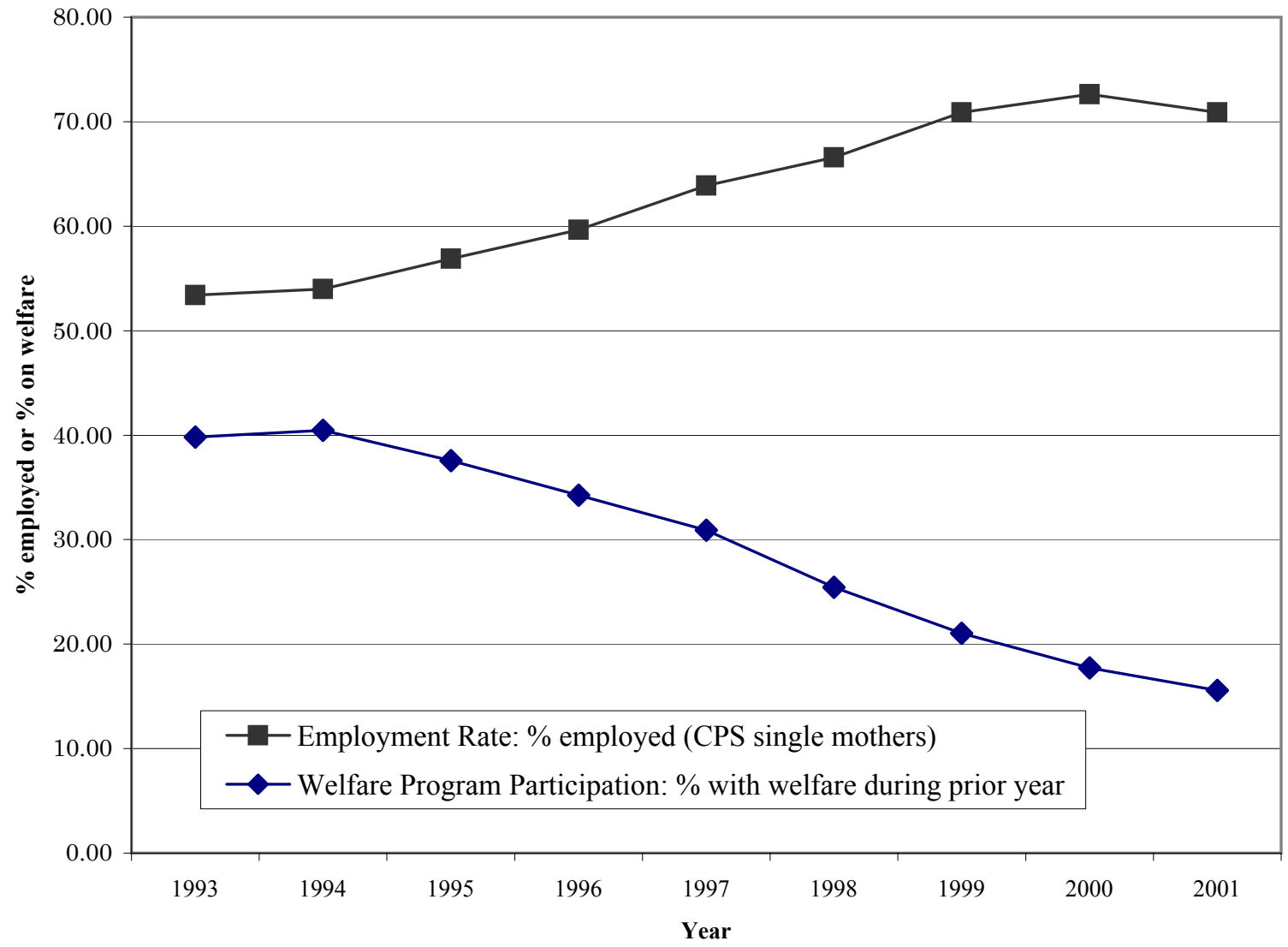

Figure II

Employment and Welfare Recipiency

(CPS sample of female household heads aged 20 to 45) 
others made broad changes. Maryland, Iowa, Michigan, and Utah, for example, eliminated nearly all JOBS exemptions [HHS, 1997], and 23 states received waivers that allowed termination of an entire family's AFDC benefit, after prolonged non-participation in JOBS.

TANF further emphasized employment, and devolved to the states responsibility for program design. TANF required states to have $50 \%$ of recipients participating in work or work related activities for 30 hours a week by 2002 (caseload reduction could help offset this). Because of the higher goals and potential funding penalties, the states designed more aggressive programs than those under JOBS by increasing provision of activities, as well as enforcement and oversight. TANF's implementation shifted activity emphasis toward paid employment, in part because it limited the amount of job search, training and education activities that could satisfy the state participation requirements. For example, TANF mandated that no more than four weeks of consecutive job search per recipient could be counted, while only $20 \%$ of recipients counted as participating in work could be individuals in vocational education or secondary school. States set deadlines for recipients to be working, and sanctions for non-compliance were strengthened by the states' increased ability to deny recipients any cash benefits.

Under JOBS, state programs emphasized improvement efforts like training, and sometimes did not count labor force work toward the activities requirement. Under TANF, all states allow work, and many states now have mandatory requirements for some recipients to work in exchange for welfare payments early in their case history; in addition job search requirements can be imposed while program applications are pending. Some states impose a structured order of activities, say, for example, job readiness classes followed by job search, then paid employment, or if paid employment is not found, then community service or another period of supervised job search. Failure to gain employment for many recipients now means required community service, or subsidized employment. Not following the rules, or not taking an assignment, results in loss of benefits, or at least the adult portion of the family's cash grant.

Other policy changes occurred during the 1990s. TANF removed welfare's entitlement status, allowing states to deny recipients benefits regardless of whether they met income eligibility guidelines. The legislation instituted a limit of 60 months of federally-funded benefits that could be collected by any one individual, and some states responded with even shorter limits. Medicaid has slowly grown apart from welfare during the decade. The states expanded transitional programs to help single parent families keep their Medicaid insurance after leaving 
Table I

\begin{tabular}{|c|c|c|c|c|c|c|c|c|c|}
\hline \multicolumn{10}{|c|}{ Age of Youngest Child Exemption (in Months) } \\
\hline state & 2001 & 2000 & 1999 & 1998 & 1997 & 1996 & 1995 & 1994 & 1993 \\
\hline Alabama & 36 & 36 & 36 & 36 & 36 & 36 & 36 & 36 & 36 \\
\hline Alaska & 12 & 12 & 12 & 12 & 36 & 36 & 36 & 36 & 36 \\
\hline Arizona & 12 & 12 & 12 & 12 & 12 & 12 & 24 & 24 & 24 \\
\hline Arkansas & 3 & 3 & 3 & 3 & 12 & 12 & 12 & 12 & 12 \\
\hline California & 12 & 12 & 12 & 12 & 36 & 36 & 36 & 36 & 36 \\
\hline Colorado & 12 & 12 & 12 & 12 & 12 & 12 & 12 & 12 & 12 \\
\hline Connecticut & 12 & 12 & 12 & 12 & 12 & 24 & 24 & 24 & 24 \\
\hline Delaware & 3 & 3 & 3 & 3 & 3 & 3 & 36 & 36 & 36 \\
\hline D.C. & 12 & 12 & 12 & 36 & 36 & 36 & 36 & 36 & 36 \\
\hline Florida & 3 & 3 & 3 & 3 & 3 & 36 & 36 & 36 & 36 \\
\hline Georgia & 12 & 12 & 12 & 12 & 12 & 36 & 36 & 36 & 36 \\
\hline Hawaii & 6 & 6 & 6 & 6 & 6 & 36 & 36 & 36 & 36 \\
\hline Idaho & 0 & 0 & 0 & 0 & 3 & 36 & 36 & 36 & 36 \\
\hline Illinois & 12 & 12 & 12 & 12 & 36 & 36 & 36 & 36 & 36 \\
\hline Indiana & 3 & 3 & 3 & 12 & 36 & 36 & 36 & 36 & 36 \\
\hline Iowa & 0 & 0 & 0 & 0 & 3 & 6 & 6 & 6 & 36 \\
\hline Kansas & 12 & 12 & 12 & 12 & 12 & 36 & 36 & 36 & 36 \\
\hline Kentucky & 12 & 12 & 12 & 12 & 12 & 36 & 36 & 36 & 36 \\
\hline Louisiana & 12 & 12 & 12 & 12 & 12 & 12 & 12 & 12 & 12 \\
\hline Maine & 12 & 12 & 12 & 12 & 24 & 24 & 36 & 36 & 36 \\
\hline Maryland & 12 & 12 & 12 & 12 & 12 & 36 & 36 & 36 & 36 \\
\hline Massachusetts & 24 & 24 & 24 & 24 & 24 & 24 & 36 & 36 & 36 \\
\hline Michigan & 3 & 3 & 3 & 3 & 3 & 12 & 12 & 12 & 12 \\
\hline Minnesota & 12 & 12 & 12 & 12 & 36 & 36 & 36 & 36 & 36 \\
\hline Mississippi & 12 & 12 & 12 & 12 & 36 & 36 & 36 & 36 & 36 \\
\hline Missouri & 12 & 12 & 12 & 12 & 36 & 36 & 36 & 36 & 36 \\
\hline Montana & 0 & 0 & 0 & 0 & 0 & 12 & 12 & 36 & 36 \\
\hline Nebraska & 3 & 3 & 3 & 3 & 12 & 12 & 12 & 12 & 12 \\
\hline Nevada & 12 & 12 & 12 & 12 & 12 & 36 & 36 & 36 & 36 \\
\hline New Hampshire & 24 & 24 & 24 & 24 & 36 & 36 & 36 & 36 & 36 \\
\hline New Jersey & 3 & 3 & 3 & 3 & 24 & 24 & 24 & 24 & 24 \\
\hline New Mexico & 12 & 12 & 12 & 12 & 36 & 36 & 36 & 36 & 36 \\
\hline New York & 12 & 12 & 12 & 36 & 36 & 36 & 36 & 36 & 36 \\
\hline North Carolina & 12 & 12 & 60 & 60 & 60 & 60 & 36 & 36 & 36 \\
\hline North Dakota & 4 & 4 & 4 & 4 & 24 & 36 & 36 & 36 & 36 \\
\hline Ohio & 12 & 12 & 12 & 12 & 12 & 36 & 36 & 36 & 36 \\
\hline Oklahoma & 3 & 3 & 3 & 3 & 12 & 12 & 12 & 12 & 12 \\
\hline Oregon & 3 & 3 & 3 & 3 & 3 & 12 & 12 & 12 & 12 \\
\hline Pennsylvania & 12 & 12 & 12 & 12 & 12 & 36 & 36 & 36 & 36 \\
\hline Rhode Island & 12 & 12 & 12 & 12 & 36 & 36 & 36 & 36 & 36 \\
\hline South Carolina & 12 & 12 & 12 & 12 & 12 & 36 & 36 & 36 & 36 \\
\hline South Dakota & 3 & 3 & 3 & 3 & 12 & 12 & 12 & 12 & 12 \\
\hline Tennessee & 4 & 4 & 4 & 4 & 4 & 36 & 36 & 36 & 36 \\
\hline Texas & 24 & 36 & 48 & 48 & 60 & 36 & 36 & 36 & 36 \\
\hline Utah & 0 & 0 & 0 & 0 & 0 & 0 & 36 & 36 & 36 \\
\hline Vermont & 18 & 18 & 18 & 18 & 18 & 18 & 18 & 36 & 36 \\
\hline Virginia & 18 & 18 & 18 & 18 & 18 & 36 & 36 & 36 & 36 \\
\hline Washington & 3 & 3 & 3 & 12 & 36 & 36 & 36 & 36 & 36 \\
\hline West Virginia & 12 & 12 & 12 & 12 & 12 & 36 & 36 & 36 & 36 \\
\hline Wisconsin & 3 & 3 & 3 & 3 & 3 & 12 & 12 & 24 & 24 \\
\hline Wyoming & 3 & 3 & 3 & 3 & 12 & 12 & 12 & 36 & 36 \\
\hline
\end{tabular}


welfare. Also, many states raised earnings limits and made other adjustments to facilitate recipient employment when, under AFDC, steep marginal tax rates were a serious obstacle to combining work and welfare. The Earned Income Tax Credit now subsidizes low income workers with children. The federal minimum wage was increased. The Family and Medical Leave Act of 1993 forced employers to implement family oriented leave. In addition to policies promoting employment, the strong labor market increased job opportunities and average wages.

\section{A. The Age of Youngest Child Exemption}

The child age exemptions from work requirements (in months) are shown in Table I. ${ }^{4}$ In 1993, the most common exemption from JOBS requirements was having a child under 36 months old. By 2000 and 2001, the most common TANF limit was 12 months. Welfare-to-work efforts have traditionally exempted mothers with young children. For example, under JOBS the federal guideline was to exempt mothers with a child under 3 from participating in any JOBS activities, although states could reduce that exemption. JOBS also exempted the ill, incapacitated, aged, full-time students, and pregnant women in their second or third trimester. Other exemptions included: those providing care for a child under 6 if no child care was available, not living near program offerings, or who had another "good reason" for not participating [HHS, 1997]. According to HHS, among the most common waivers sought by states was permission to limit exemptions. TANF eliminated most of these exemptions that states could use in calculating their required work participation rate, but left the age of youngest child exemption. States can disregard single parent families with children under age 1 in the calculation of the state's participation rate. ${ }^{5}$ Most states take advantage of this provision, and some states offer more generous exemption age limits.

One question is what people know about the exemption. Studies of single mothers'

4. Details on how the policy is assigned to the data is discussed in section IV. If not universal within a state, the policies represent the majority of welfare recipients covered in each state.

5. The federal participation rate disregard is only allowed for 12 months per case lifetime. This limit has been removed in some versions of the proposed revisions, which would make it a somewhat short-lived restriction. However, because of this federal limit, some states have imposed similar restrictions. This would affect less than $1 \%$ of the total sample. The restriction came with TANF so not many women actually face this restriction yet. This is addressed below. Guidelines for the exemption in state plans are clear. For example, North Carolina's Work First plan, under its section outlining work requirements says, "A single parent of a child less than one year old shall not be required to comply with work requirements until the child turns one," See State of North Carolina, Public Law 104-193. 
knowledge of program rules indicates most recipients understand some basic workings of welfare, but lack deep understanding of more complicated changes under TANF [see Cherlin, et. al., 2002]. Anderson [2002] studied how much recipients knew about changes in the work incentives in Michigan that came with TANF, although he did not specifically look at exemptions. Nevertheless, his interviews showed that recipients knew about the rules, but not the complicated incentives involved. Recipients knew transitional benefits were available, and what was available. For example, $90 \%$ of respondents knew Medicaid eligibility would remain for welfare leavers, but not details about how the coverage might change. Similarly, he noted that recipients understood there would be a flat earnings disregard of $\$ 200$, plus a percentage above that, but they did not understand how that formula was applied to their benefits. The youngest child exemption has existed in some form since 1988, so presumably individuals familiar with JOBS or welfare would understand it. Moreover, it is not difficult to grasp.

Official recognition of the exemption is positive. ${ }^{6}$ Conversations with state officials in several states indicated that the exemption is enforced by staff, and that single mothers who satisfy the exemption are not asked to enroll in work programs, nor asked to work. The work by exempt recipients is by choice. Also, because of the readily identified age cutoffs, officials noted the exemption is easily applied by caseworkers and state level staff. In states that were contacted, officials knew right away what the current exemption was, and usually how long it had been in place. The exemption appears to offer a useful comparison group for the bulk of the nation's caseload. ${ }^{7}$

\section{PREVIOUS RESEARCH ${ }^{8}$}

Separately identifying the effects of specific policy changes, since many occurred simultaneously, and the influence of the economic growth of the 1990s, has been a difficult problem for the empirical literature studying welfare reform. Certainly, the labor market

6. These assessments come from conversations with state officials from 16 states, and from the Urban Institute staff. This was noted as one exemption under TANF that is universally applied.

7. Several state officials also said that they were not particularly concerned with exempt non-workers who might be included in the federal participation rate calculation. One state official suggested time limits would come quickly enough that it would be difficult for there to be many women who could afford to be exempt for very long, and thus did not consider repeated use of the exemption a problem for the states. 
contributed to the changes. For example, research by Holzer [2002] indicates demand for welfare recipients was particularly strong during the 1990s, enough to easily absorb the recipients moving into the labor force. However, the extent to which the economy or policies influenced behavior has been the central question of most studies. Among the earliest, two reports by the Council of Economic Advisors (CEA) attributed most of the caseload decline to a strong labor market, but credited TANF for one-third of the reductions [CEA 1999, 1997].

The CEA analysis also included a variable for the age of youngest child exemption. The estimates showed that the exemption, and the reductions in the exemption, were not correlated with caseload reduction. The estimates were not large or significant, and in one specification had the wrong sign, indicating a potential positive relationship between a higher exemption and lower caseloads. The CEA concluded that reducing the exemption did not "play a role" in declining caseloads, a result replicated in this Appendix. Despite the CEA studies receiving criticism and review [Figlio and Ziliak, 1999, and Moffitt, 1999, for example), the age of youngest child exemption has been otherwise largely ignored by researchers.

A tidal wave of research followed reform. For example, Figlio and Ziliak [1999] argue the caseload decline was almost entirely because of the business cycle. In an Urban Institute report, Bell [2001] reviewed research on caseload reduction and concluded that the existing research failed to convincingly link specific characteristics of the policy reforms to the caseload decline. Still, others find varying effects of reform. (For results on TANF's behavioral effects see Moffitt [1999], Wallace and Blank [1999], Schoeni and Blank [2000], Kaestner and Kaushal [2001], Levine and Whitmore [1998]). Alternatively, research shows other policies (like the Earned Income Tax Credit) have increased the work of welfare recipients and also contributed to caseload decline [Blank, Card and Robbins, 1999; Currie and Grogger, 2001; Meyer and Sullivan, 2001; Meyer and Rosenbaum, 1999; Dickert-Conlin and Holtz-Eakin, 2000]. Using pre-TANF data, Ribar [2002] finds local markets that more readily accommodate the skills of single mothers are a much more important determinant of employment than state policy. Overall, the link between TANF's work requirements and rising single mother's employment are merely suggestive. The initial assessments do not differentiate among the many aspects of the reforms, frequently identifying only an indicator variable for the policy reforms. Research has just begun to assess specific details. For example, Grogger [2001] analyzed state time limit policies, to 
which he attributes $7 \%$ of the employment increase. ${ }^{9}$

Most of what is known about mandatory work rules for recipients comes from demonstration projects. The projects evaluated specific welfare-to-work programs in cities around the country, primarily under the JOBS program. For example, California's GAIN program compared work-first (employment emphasis) programs to training-first programs. Evaluation by the Manpower Demonstration Research Corporation (MDRC) showed large caseload reduction and employment increases came from an emphasis on work. ${ }^{10}$ In Congressional testimony, Lynn Karoly [2001] summarized this research. Referring to 13 local program sites, she concluded the work requirements, under the JOBS program, caused employment increases and caseload declines. A summary from the U.S. Department of Health and Human Services (HHS) on 20 local projects noted employment-based programs were more successful than education-based programs, but favored offering a mix of activities [HHS, 2000]. Naturally, there is dissent. Education and training may have a longer-term impact on selfsufficiency because requiring work moves recipients into tenuous employment, from which they may be unlikely to leave the welfare rolls for long. ${ }^{11}$

Updating findings from California's GAIN program, Hotz, Imbens, and Klerman [2001] find that, compared to less intensive programs in neighboring counties, the initial success of Riverside California's work-first program has worn off over time. ${ }^{12}$ In fact, nearby counties that kept training based programs had employment increases that surpassed Riverside's program in the nine year follow-up. Berlin [2002], in the MDRC's guide to reauthorization, notes no clear winner in what works. While education-based programs produce former recipients whose earnings approach those of work-first graduates, there is no evidence the lost wages incurred while training are recovered. However, many approaches show increased employment. For

9. See also Grogger and Michalopoulos [1999]. Also, see Grogger [2003] for a nice study of the dynamics.

10. See Hotz, Imbens, and Klerman [2001] for discussion.

11. See Karoly [2001], Knab, Bos, Friedlander, and Weissman [2000], and HHS/DOE [2001] for summaries. See Burtless and Friedlander [1995] for this discussion of education vs. work focused programs. Zedlewski, [1999] compared 12 states' JOBS programs and found those with tougher requirements saw higher levels of employment.

12. Riverside's program is called "work-first" here, compared to other programs in the early 1990s. However, now it might also be considered a "mixed-strategy" program with an emphasis on employment [Berlin, 2002]. 
example, income supplements that increase the monetary incentives for employment were also noted as effective. The recommendations also say that without credit for caseload reduction, many states would not meet higher federal requirements. The MDRC report did not specifically recommend increasing the work requirements with TANF re-authorization. ${ }^{13}$

\section{DATA AND VARIABLES}

The analyses are based primarily on pooled cross sections of unmarried, single-female headed families with children age 10 and under, from the March CPS, Annual Demographic Supplement (ADS), from years 1993 to 2001, although a sample of married mothers are used as a control group. The single mothers were aged 20 to $45 .{ }^{14}$ Teenagers, older mothers and those with older children were not used in order to keep the sample reasonably homogeneous (teenage recipients often face different rules). The sample contains 27,786 person-year observations on single mothers from 1993 to 2001, of whom 13,278 were in states following the implementation of the state TANF plans. ${ }^{15}$ Unfortunately, the ADS has no information on child care, and no information on whether an individual is a welfare recipient at the time of the interview, only prior year's recipiency. ${ }^{16}$

Employment is the dependent variable of interest. The employment choice is considered because the macroeconomic change has been on the intensive rather than extensive margin [see

13. Extending job program coverage was a natural reaction of the states to TANF. Mathematica Policy Research addressed this in a study of Iowa's PROMISE JOBS program. Two groups of single mothers with children under age 3 were compared. One was left with traditional AFDC, and the other was subject, for two-years, to reforms implemented in Iowa in 1993. While the program changes were more than just work requirements, Mathematica estimated a $6 \%$ increase in employment in the treatment group who lost the exemption. For the same period here, prior to TANF, estimates imply that the loss of the exemption would lead to a similar employment increase. See appendix, Table IX, column 11.

14. Using families with only an unmarried mother is largely due to the difficulty in accurately pairing relationships in the CPS. It is not an uncommon sample definition in the literature, and selection is discussed in a footnote later. See London [1998] for a discussion of the identifying households and mother-only families in the CPS. For examples in the literature that condition on single motherhood see Meyer and Rosenbaum [1999], and Keane and Moffitt [1998].

15. See Moffitt, [1999] and Moffitt and Ver Ploeg, [2002] for discussion of the lack of alternative data sets when cross-state variation in policies is needed or useful for analysis.

16. Due to the CPS rotation sequence of interviews, there are duplicate observations in the sample. Households were matched across years so that the standard errors in the analysis could be adjusted. However, id variables redesigned in 1995 prevented matching across that cutoff. This does not affect the bulk of the analysis, since most is post-TANF, but is recognized as unappealing in the computation of standard errors in three specifications shown in the appendix. 
Table II

\begin{tabular}{|c|c|c|c|}
\hline \multicolumn{4}{|c|}{ Variable Means and Descriptions } \\
\hline Variable name & Mean & Std. Dev. & Description \\
\hline working & 0.626 & 0.484 & $=1$ if employed \\
\hline welfare & 0.299 & 0.458 & $=1$ if received welfare during previous year \\
\hline exempt & 0.201 & 0.400 & $=1$ if exempt from work requirements due to age of youngest child \\
\hline age & 30.759 & 6.458 & age of single mother at interview \\
\hline widow & 0.025 & 0.156 & $=1$ if a widow \\
\hline urban & 0.794 & 0.404 & $=1$ if in MSA \\
\hline oldest & 0.091 & 0.287 & $=1$ if child 13 or over in household \\
\hline disabl & 0.032 & 0.177 & $=1$ if claim work limiting disability \\
\hline nodip & 0.228 & 0.419 & $=1$ if did not finish high school \\
\hline highsc & 0.692 & 0.462 & $=1$ if completed four years of high school \\
\hline colleg & 0.081 & 0.272 & $=1$ if completed four years of college \\
\hline black & 0.275 & 0.446 & $=1$ if Black \\
\hline natvam & 0.021 & 0.143 & $=1$ if Native American \\
\hline asian & 0.017 & 0.129 & $=1$ if Asian \\
\hline hisp & 0.214 & 0.410 & $=1$ if Hispanic \\
\hline empgro & 2.179 & 1.505 & employment growth from previous year x 100 \\
\hline unemp & 5.454 & 1.553 & unemployment rate \\
\hline lunemp & 5.793 & 1.753 & unemployment rate a year earlier \\
\hline chldsup & 1171.169 & 3131.523 & real child support payments \\
\hline alimony & 69.176 & 1093.241 & real alimony payments \\
\hline disinc & 27.737 & 547.930 & real disability income \\
\hline ccex & 0.712 & 0.453 & $=1$ if potentially eligible for work exemption because of child care \\
\hline nokids & 1.919 & 1.042 & number of children \\
\hline waiver & 0.178 & 0.383 & $=1$ if state had waiver in place, but not TANF plan \\
\hline TANF & 0.478 & 0.500 & $=1$ if $\mathrm{TANF}$ plan implemented \\
\hline minwage & 1.640 & 0.070 & $=\log$ real minimum wage \\
\hline manuwg & 6.337 & 0.124 & $=$ log real weekly manufacturing wages \\
\hline famcap & 0.283 & 0.450 & $=1$ if family cap policy in place \\
\hline splimit & 1.327 & 1.616 & $=100 /($ month limit on continuous spell of recipiency $)$ \\
\hline lflimit & 0.884 & 1.080 & $=100 /($ month lifetime limit on recipiency $)$ \\
\hline asset & 1993.975 & 1683.579 & real asset limit for eligibility \\
\hline divert & 0.173 & 0.378 & $=1$ if diversion assistance available \\
\hline $\operatorname{trans}$ & 10.471 & 7.175 & months of transitional child care available \\
\hline benefit & 447.005 & 173.592 & real max benefit, family of three \\
\hline sancf & 38.530 & 23.221 & severity of initial sanction (out of 100 ) \\
\hline permscn & 0.056 & 0.230 & $=1$ if sanctions can lead to permanent loss of benefits \\
\hline earnlmt & 708.087 & 221.431 & earnings limit at start of recipiency \\
\hline yest1 & 0.096 & 0.294 & $=1$ if youngest child under 1 \\
\hline yest2 & 0.111 & 0.314 & $=1$ if youngest child is 1 \\
\hline yest3 & 0.108 & 0.310 & $=1$ if youngest child is 2 \\
\hline yest4 & 0.104 & 0.305 & \\
\hline yest5 & 0.100 & 0.300 & \\
\hline yest6 & 0.095 & 0.293 & \\
\hline yest7 & 0.089 & 0.285 & \\
\hline yest8 & 0.085 & 0.278 & \\
\hline yest9 & 0.076 & 0.265 & \\
\hline yest10 & 0.071 & 0.257 & \\
\hline yest11 & 0.066 & 0.249 & $=1$ if youngest child is 10 \\
\hline year1 & 0.126 & 0.332 & $=1$ if 1993 \\
\hline year2 & 0.125 & 0.331 & $=1$ if 1994 \\
\hline year3 & 0.121 & 0.326 & $=1$ if 1995 \\
\hline year 4 & 0.108 & 0.311 & $=1$ if 1996 \\
\hline year5 & 0.108 & 0.310 & $=1$ if 1997 \\
\hline year6 & 0.105 & 0.307 & $=1$ if 1998 \\
\hline year7 & 0.106 & 0.308 & $=1$ if 1999 \\
\hline year8 & 0.105 & 0.306 & $=1$ if 2000 \\
\hline year9 & 0.097 & 0.296 & $=1$ if 2001 \\
\hline $\mathrm{n}:$ & 27,786 & & \\
\hline
\end{tabular}


Meyer, 2002]. Employment equals 1 if, at the March CPS interview, the single mother was employed, or was at home but claimed to have a job. Age of youngest child enters as an indicator variable for each age up to 10. Other variables include indicators for years and states, interactions with child's age, and state by state unemployment rates, lagged unemployment rates, and employment growth rates assigned for each state by year to each individual. Individual characteristics include age, race, widowhood, indicators for level of schooling, urban area, a work-limiting disability, number of children, and having an older child in the home. Policy information is from The Urban Institute, the State Policy Documentation Project, state TANF plans, and follow-up phone calls to state administrators. Variable descriptions are in Table II.

Assignment to the exempt category corresponds to the policy information, using the age cutoffs as shown in Table I. ${ }^{17}$ The data contains 5,572 exempt single mothers. Each woman, at the March interview, who would be eligible for the exemption from program work requirements was coded as being exempt. However, the CPS does not record exact child birth dates, only their ages. Because of this, the analysis rounded the exemption down to the nearest whole year so that non-exempt women would not be categorized as exempt. For example, if a mother with a one year old child was in a state where the exemption was 18 months, then she would not be included in the exempt group, even though her child may be under 18 months. This affects 33 person-year observations in the empirical analysis, and none of the results. ${ }^{18}$ Also, women who might be subject to restrictions on the exemption, because they have more than one child and live in a state that imposes a lifetime limit on the exemption, are identified, and the results' sensitivity to this is discussed and tested in the Appendix. This potentially affects 209 observations in the sample. The analysis shows this does not affect the estimated employment patterns, or conclusions. Other exemptions, disability for example, might affect the group subject to program work

17. Majority coverage for the exemption is not seen as an empirical or measurement problem here for a few reasons. First, for almost all the states the exemption was statewide policy. Second, for places were it was not, this was mostly due to demonstration projects run in areas that represented small parts of the caseloads, and would not have affected entrants who applied to be part of the "normal" caseload in a state. Third, many of these projects ended with TANF's passage. Majority coverage also implies that when a state that implemented policy changes county by county, like Virginia, the policy applied it to most of the state. Because only March observations were used, gradual implementation was either not begun or mostly complete by the interview dates. Also, for each agestate-year cell, there are not enough cases affected on the margin that any one state's policy in a single year would significantly change the results.

18. Specifications under the alternative assumption are shown in the Appendix. 
requirements, but such exemptions affect only a small portion of the recipient population. According to HHS, approximately $14 \%$ of recipients were exempt for other reasons. ${ }^{19}$ The empirical results are robust to the inclusion of related policies such as variation in state recipiency time limits.

One final note concerns the difference between the 3 month exemption and those states that offer no exemption. The 3 month exemptions are similar to the federal Family and Medical Leave Act (FMLA), which mandates 12 weeks of unpaid leave for new mothers. However, states that have no exemption, to some degree, allow a leave for women with new children similar to FMLA guidelines. While the TANF plans say there is no age of youngest child exemption, in practice it would be difficult to differentiate between a 3 month exemption and no exemption, in states that provide for 12 weeks of leave for medical reasons for the mother and child. Because the 0 and 3 month exemptions are meant to be only a short-term leave from work programs, each has been coded as no exemption here. The alternative assignment is analyzed in the Appendix. ${ }^{20}$ In the subsequent analysis, this variation in policy will be captured in part by indicators for having a newborn (child under 1) interacted with the state indicators. Indicators for each child's age-state pair will capture unobserved state-specific differences in the impact of having a newborn on employment. This addresses any unobserved differences between states in their treatment of mothers of children under one.

\section{EMPIRICAL ANALYSIS}

The exemption allows TANF's work requirements to be separated from a large group of potential causes for the employment increases, and the analysis here specifically identifies the effect of exempting single mothers from work requirements. The goal is to control for any differences between the exempt and not exempt, such that the only remaining distinction between the two groups is that exempt women are not required to work or to be part of work programs. The differences across states and over time in the exemption age allows exempt and not exempt mothers to be compared holding child's age constant (or alternatively, comparisons

19. These are all welfare cases exempt from federal participation rate calculations except those exempt due to tribal exemptions, teen parent in education, and the age of youngest child exemption. Native Americans are identified in the data, and teens are excluded in the analysis.

20. For analysis below with years 1993-2001, a variable for state leave policies did not affect results. Information on the Family and Medical Leave Act and related state policy comes from [Baum, 2003]. 


\section{FIGURE III}

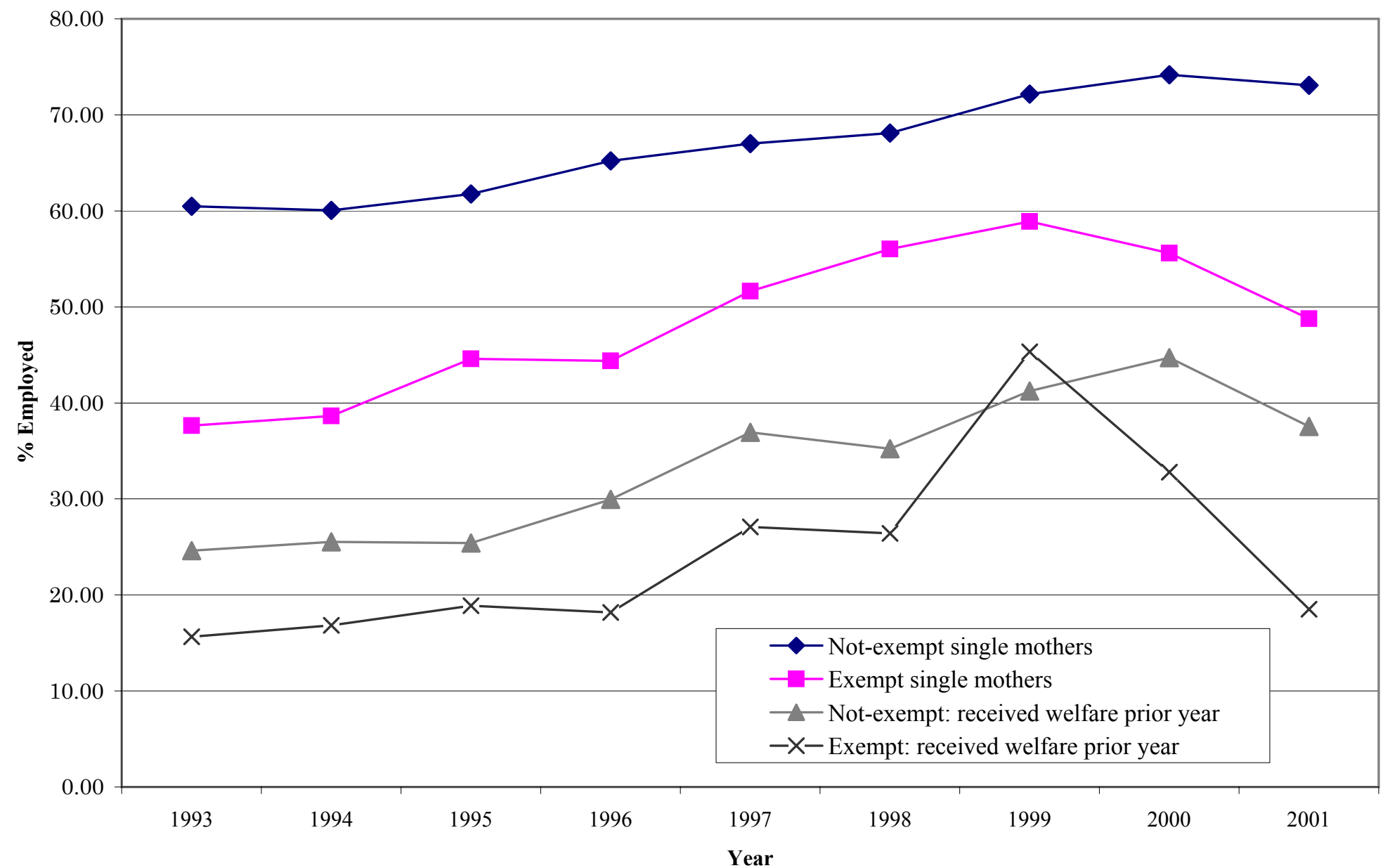

Figure III

Employment Rates: by Exemption Status 
Table III

\begin{tabular}{cccccc}
\hline \hline \multicolumn{5}{c}{ Employment Rates: } \\
\hline $\begin{array}{c}\text { Category: } \\
\text { year: }\end{array}$ & $\begin{array}{c}\text { entire sample } \\
\text { \% working }\end{array}$ & $\begin{array}{c}\text { not exempt } \\
\text { single mothers }\end{array}$ & $\begin{array}{c}\text { exempt } \\
\text { single mothers }\end{array}$ & $\begin{array}{c}\text { not exempt } \\
\text { on welfare* }\end{array}$ & $\begin{array}{c}\text { exempt } \\
\text { on welfare* }\end{array}$ \\
1993 & 53.39 & 60.48 & 37.63 & 24.60 & 15.65 \\
1994 & 53.98 & 60.06 & 38.64 & 25.52 & 16.85 \\
1995 & 56.88 & 61.75 & 44.60 & 25.41 & 18.88 \\
1996 & 59.65 & 65.20 & 44.39 & 29.94 & 18.18 \\
1997 & 63.88 & 67.00 & 51.64 & 36.93 & 27.08 \\
1998 & 66.59 & 68.09 & 56.04 & 35.22 & 26.42 \\
1999 & 70.87 & 72.17 & 58.89 & 41.25 & 45.33 \\
2000 & 72.62 & 74.16 & 55.60 & 44.71 & 32.79 \\
2001 & 70.88 & 73.08 & 48.77 & 37.53 & 18.52 \\
* On welfare means they collected welfare at some point during the year prior to their March \\
CPS interview. Employment information is for March, at their interview. Exempt and not \\
exempt applies to whether or not they were classified as exempt at the March interview. The \\
on welfare groups are a subset of single mothers. \\
\hline \multicolumn{7}{l}{}
\end{tabular}




\section{Table IV}

\begin{tabular}{|c|c|c|c|}
\hline \multicolumn{4}{|c|}{$\begin{array}{l}\text { Employment Rate Difference-in-Differences Estimates: } \\
\text { Exempt vs. Not Exempt, Married vs. Single } \\
\end{array}$} \\
\hline Age of youngest child: & Single Mothers & Married Mothers & Differences \\
\hline Child < Age 1: & $\%$ employed & $\%$ employed & single - married \\
\hline not exempt: & 57.58 & 56.89 & 0.69 \\
\hline$\left(\sigma_{\mu}\right)$ & $(2.725)$ & $(1.207)$ & $(0.335)$ \\
\hline \multirow{4}{*}{ difference (not exempt - exempt): } & 52.06 & 53.44 & -1.38 \\
\hline & $(1.669)$ & $(0.824)$ & $(0.538)$ \\
\hline & 5.52 & 3.45 & 2.07 \\
\hline & $(0.312)$ & $(0.682)$ & $(0.284)$ \\
\hline $\mathrm{t}$-stat of difference: & 1.720 & 2.354 & 0.587 \\
\hline \multicolumn{4}{|l|}{ Child Age 1: } \\
\hline \multirow{6}{*}{ difference (not exempt - exempt): } & 60.76 & 60.04 & 0.72 \\
\hline & $(1.447)$ & $(0.707)$ & $(0.620)$ \\
\hline & 55.56 & 55.29 & 0.27 \\
\hline & $(3.136)$ & $(1.669)$ & $(0.282)$ \\
\hline & 5.20 & 4.75 & 0.45 \\
\hline & $(0.293)$ & $(0.557)$ & $(0.259)$ \\
\hline $\mathrm{t}$-stat of difference: & 1.524 & 2.648 & 0.117 \\
\hline \multicolumn{4}{|l|}{ Child Age 2: } \\
\hline not exempt: & 66.41 & 61.43 & 4.98 \\
\hline & $(1.385)$ & $(0.745)$ & $(0.625)$ \\
\hline \multirow{4}{*}{ difference (not exempt - exempt): } & 67.05 & 55.44 & 11.61 \\
\hline & $(3.553)$ & $(2.255)$ & $(0.232)$ \\
\hline & -0.64 & 5.99 & -6.63 \\
\hline & $(0.262)$ & (0.429) & $(0.220)$ \\
\hline $\mathrm{t}$-stat of difference: & -0.168 & 2.567 & -1.456 \\
\hline \multicolumn{4}{|c|}{$\begin{array}{l}\text { Shown categories of married mothers are in the same state, period and child's age category as } \\
\text { compared single mothers. Employment rate is the percentage of each category who said they were } \\
\text { employed at their CPS interview. Sample used is the CPS sample of } 13,278 \text { single mothers living in } \\
\text { states where TANF plans had been implemented. Standard errors are in parentheses. }\end{array}$} \\
\hline
\end{tabular}


within states, before and after a policy change). The substantial variation in policy will also allow characteristics to be interacted so that in the analysis economic and policy forces can affect the not exempt and exempt differently according to the age of their children, and still identify, with a reasonable amount of precision, the employment effect of exempting single mothers from TANF's work requirements.

Figure III shows the employment trends of exempt and non-exempt single mothers, and separately those on welfare the prior year. For each group, employment rose during the period of reform. The overall employment increase from 1996 to 1998, captured in many studies, is due in part to increased work from exempt women. Their employment rises steeply during TANF's implementation period and immediately thereafter. Of the exempt welfare recipients, the fraction working rose $2 \frac{1}{2}$ times in three years, proportionally more than those women actually subject to the work rules. (The corresponding employment statistics are in Table III). The exempt single mothers' increase also coincides with the exemption being lowered by many states, so the pattern represents women who are less likely to work on average because their children are younger.

Next, holding constant the age of youngest child, a comparison between the employment rates of the exempt and not exempt under TANF is shown in Table IV. The employment rates are shown for single mothers, divided into categories based on the age of their youngest child. Then, within each child's age category, the employment rate of the exempt in that category is subtracted from the employment rate of the not exempt. Thus, holding constant child's age, this computes how much more likely the not exempt women are to work than the exempt. For mothers of children under age 1, the not exempt have an employment rate of $57.58 \%$ and the exempt have an employment rate of $52.06 \%$, a difference of 5.52 percentage points. Next, for mothers of one year olds, the difference is similar. The employment rate for those subject to work requirements is 5.2 percentage points higher than for those not exempt from work.

However, these differences are identified primarily by across-state variation. For mothers of one year olds, the exempt are in different states than the not exempt. To control for differences in state labor markets, the employment rates of the same categories of married women are compared, because married women as a group should be unaffected by welfare policy. Their employment rates are also shown in Table IV. The married mothers have employment differences between the groups of states that are similar to the single mothers. For 
example, in the states with no exemption for mothers of children under age 1 , the married women with children under age 1 are 3.45 percentage points more likely to be working than the exempt category of married mothers of children under age 1.

After subtracting the differences among married mothers from the employment differences of single mothers, the only notable positive effect of the work requirements is found for single mothers with children younger than age 1 . That category of not exempt single mothers is 2.07 percentage points more likely to be working, after differencing out the across-state differences among married mothers. In other age categories, mothers with children age 1, or age 2 (or age 3 which is not shown), there is no effect. At older ages, the estimated effect on employment due to required work is negative. This highlights simply what the next empirical analysis shows - after controlling for child's age and state differences, employment behavior under TANF of exempt and not exempt single mothers is indistinguishable.

\section{$\underline{\text { V.A. Estimation }}$}

Two issues (or assumptions) in particular deserve discussion. First, for the results to be interpreted as identifying the effect of exempting single mothers, the analysis assumes that the effect of child's age on a mother's employment is adequately controlled for. Interpretation needs to be based on the policy, and not because women with young children are on average less likely to work, but more likely to be exempt. The exempt women are similar to the not exempt, but the two groups differ by construction because the exemption is based on child's age. Table $\mathrm{V}$ compares the two groups' mean characteristics. For example, not only do the exempt women have younger children, not surprisingly they themselves are slightly younger. To control for youngest child's age, separate youngest child age dummies are included, and then are also interacted with state and time indicators, so that, as an example, a single dummy would indicate having a one-year-old in Iowa, and then another dummy would indicate having a two-year-old in Iowa, and so on.

Second, the analysis assumes assignment to the exempt group is exogenous. For example, one case considered was whether women with low tastes for work were increasing fertility to become exempt, but as may be clearer later, there is no evidence of such a bias. ${ }^{21}$

21. This may be clearer after viewing the empirical estimates below, but there was no evidence here that women with low tastes for work were trying to get into the exempt group, and the exemption is not correlated with 
Table V

\begin{tabular}{|c|c|c|c|c|}
\hline \multicolumn{5}{|c|}{ Characteristics of Exempt and Not Exempt Single Mothers } \\
\hline \multirow[b]{2}{*}{ Variable } & \multicolumn{2}{|c|}{ Not Exempt } & \multicolumn{2}{|c|}{ Exempt } \\
\hline & Mean & Std. Dev. & Mean & Std. Dev \\
\hline working & 0.670 & 0.470 & 0.451 & 0.498 \\
\hline age & 31.689 & 6.317 & 27.055 & 5.632 \\
\hline urban & 0.789 & 0.408 & 0.814 & 0.389 \\
\hline older child in home & 0.107 & 0.309 & 0.026 & 0.159 \\
\hline disabl & 0.034 & 0.180 & 0.028 & 0.164 \\
\hline did not finish H.S. & 0.210 & 0.407 & 0.299 & 0.458 \\
\hline high school & 0.702 & 0.457 & 0.649 & 0.477 \\
\hline college & 0.088 & 0.283 & 0.053 & 0.224 \\
\hline fraction black & 0.265 & 0.441 & 0.314 & 0.464 \\
\hline native American & 0.021 & 0.143 & 0.022 & 0.145 \\
\hline Asian & 0.018 & 0.132 & 0.014 & 0.118 \\
\hline Hispanic & 0.200 & 0.400 & 0.267 & 0.442 \\
\hline employment growth (\%) & 2.170 & 1.475 & 2.219 & 1.618 \\
\hline unemployment rate & 5.310 & 1.500 & 6.029 & 1.629 \\
\hline lagged unemp. Rate & 5.625 & 1.711 & 6.463 & 1.758 \\
\hline number of children & 1.888 & 1.005 & 2.041 & 1.172 \\
\hline fraction under waiver & 0.163 & 0.369 & 0.241 & 0.428 \\
\hline fraction under TANF & 0.534 & 0.499 & 0.255 & 0.436 \\
\hline log min wage & 1.644 & 0.071 & 1.624 & 0.067 \\
\hline log man. Wage & 6.341 & 0.127 & 6.321 & 0.109 \\
\hline family cap & 0.314 & 0.464 & 0.158 & 0.365 \\
\hline real welfare benefit & 444.204 & 168.138 & 458.171 & 193.431 \\
\hline$\%$ with child under 1 & 0.015 & 0.123 & 0.415 & 0.493 \\
\hline$\%$ w/child age 1 & 0.062 & 0.242 & 0.304 & 0.460 \\
\hline$\%$ w/child age 2 & 0.069 & 0.254 & 0.260 & 0.439 \\
\hline$\%$ w/child age 3 & 0.127 & 0.333 & 0.012 & 0.111 \\
\hline$\%$ w/child age 4 & 0.123 & 0.328 & 0.009 & 0.092 \\
\hline n: & 22,214 & & 5,572 & \\
\hline
\end{tabular}


These assumptions, together saying that women with two year olds are not systematically different from women with three year olds in unobservable ways, rest on the premise that mothers of three year olds were the prior year's mothers of two year olds. They should not be substantially different in ways other than the actual age of their child, which the analysis addresses and which for a mother is not a choice. ${ }^{22}$ For example, two year olds may require more energy than three year olds, or place different time demands on mothers, or need different child care arrangements. For whatever the underlying reason, the mean effect on employment of having a two year old will be controlled for separately from the effect of having a three year old, or one year old, etc. But, outside the fact that their children are different ages, presumably the exempt and not exempt women are reasonably similar, or at least not dissimilar in such a way that it's correlated across all states and periods with the exemption. Of course, observable characteristics like mother's age and race are also modeled. These assumptions imply that after controlling for child's age, the exempt and not-exempt are otherwise alike.

The following equation offers an estimate of the impact of work requirements:

$Y_{i}=\beta_{0}+\beta_{1} \times$ Exempt $_{i}+\beta_{2} \times X_{i}+\sum_{s=1}^{S-1} \beta_{3, s} \times$ State,$i+\sum_{a=1}^{A-1} \beta_{4, a} \times$ Age $a, i+\sum_{t=1}^{T-1} \beta_{5, t} \times$ Yeart,$i+\mu_{i}$

where $Y_{i}$ is the employment indicator, and Exempt ${ }_{i}$ indicates exemption status. ${ }^{23} X_{i}$ includes state labor market variables, unemployment rate, lagged unemployment rate, and the employment growth rate. It also contains personal characteristics, including indicators for

marital status or number of children.

22. Potential cohort effects were not present. Cohort fixed effect estimators produce similar results. Other estimators have been explored, including difference-in-differences estimators, matching, and also Hotz, Imbens, and Klerman [2001] Average Differential Treatment Effect, using the old JOBS program as a basis of comparison. Each uses variation in behavior corresponding to variation in cutoffs to uncover a treatment effect. Note that the difference-in-differences estimator is similar to the Regression Discontinuity estimator suggested by van der Klaauw [2002], Hahn, et.al. [1999, 2001], which compares employment rates within a small interval on either side of a cutoff. The work exemption offers a cutoff. Each estimator rests on the assumption the women on either side should not be very different. For example, women with one year olds are the prior year's women with newborns, so assuming that the parents on either side of the cutoff are otherwise the same seems valid. Then, if the exemption is 12 months, the difference in employment between women with 1 year olds vs. newborns would be due to two things, the difference in child's age, and the difference in required work. Also of note, for the parametric corollary of a matching estimator suggested by Hotz, Imbens, and Klerman [2001], the primary assumption needed to ensure their estimates' validity, aside from exogenous control group assignment, is that if the policies applied to the groups were switched, expected outcomes conditional on observables would similarly switch.

23. While presented as a linear probability model, a probit model used where $u \sim I N\left(0, \sigma^{2}\right)$ and the dependent variable in (1) and (2) is replaced by the latent variable $\mathrm{Y}^{*}{ }_{\mathrm{it}}$ with $\mathrm{Y}_{\mathrm{it}}=1$ iff $\mathrm{Y}^{*}{ }_{\mathrm{it}}\left\langle 0\right.$ and $\mathrm{Y}_{\mathrm{it}}=0$ otherwise. The linear probability models had similar results, but predictions outside $[0,1]$. 
mother's age, schooling, urban location, an older child, widowhood, disability, and number of children. There are sets of indicators for age of youngest child, Age $_{a}, a=0, \ldots, 10$, state of residence, State $_{s}, s=1, \ldots, 51$, and Year $_{t}, t=1997, \ldots, 2001$. Only periods after state TANF plans had been implemented are used, which will give a clearer interpretation of TANF's work requirements. ${ }^{24}$ The marginal effect estimated by $\beta_{1}$ is the difference in the probability of employment attributable to being exempt from work requirements, conditional on the other covariates.

The results are shown in Table VI. The specifications start with no controls, other than the exempt indicator, and then add one set at a time for comparison, to better understand the role of each in identification, and what each set of indicators contributes. Probit results are reported as marginal effects, or the estimated change in the predicted probability of employment due to a unit change in the covariate. In other words, Table VI reports in percentage points how much the exempt employment rate is estimated to be greater than or less than the employment rate of not exempt single mothers. Column 1 shows the estimated effect of the exemption, -0.1519 , for a specification in which the exempt indicator is the only variable. The identification comes primarily from differences in mothers' employment rates across ages of their youngest child, which is correlated with the exempt status. Adding age of youngest child dummies reduces the marginal effect of the exemption to -0.0205 , which is not significantly different from zero. Column 1 shows basic correlation between the exemption and employment, but reveals the need to control for age of youngest child in order to have interpretable results.

In column 3, mother's age indicators are added to the specification in column 1, barely affecting the estimates. The age of youngest child indicators appear to be controlling somewhat for this related difference between the groups. Column 4 adds year dummies to control for aggregate trends over time, and the estimate nudges closer to zero, -0.0117. Adding employment characteristics (unemployment rate, lagged unemployment and employment growth) as shown in column 5 , makes the marginal effect change sign, but remain essentially zero at $0.0015 .{ }^{25}$

24. The appendix shows results from years prior to TANF. Also, including other policies did not affect the results. These included controls for potential child care exemptions, benefits, and the remaining variables noted in Table II, such as log minimum wages and log weekly manufacturing earnings.

25. As an ad-hoc test of the correlation between the repeated household sampling in the CPS and the exemption, a random effects regression was estimated with only the exemption and child's age indicators. A Hausman test revealed no correlation between the unobserved household component and the policy and child age 
Table VI

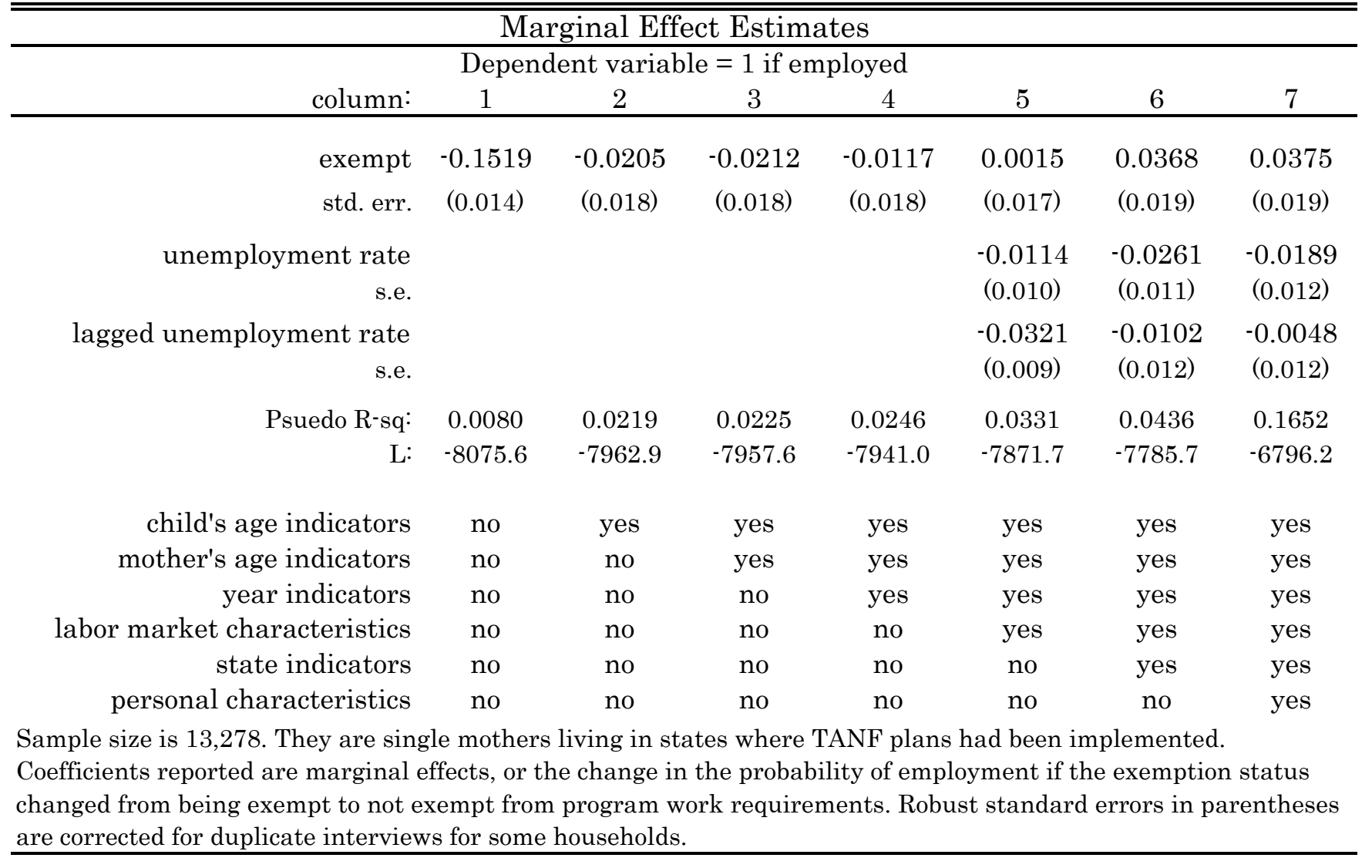


To control for unobserved state characteristics, state indicators are added in column 6 to the specification in column 5 . The estimate grows to 0.0368 , implying that exempt single mothers, conditional on the covariates, are more likely to be employed. Then, as shown in column 7, adding personal characteristics does not change this relationship and the estimated marginal effect of being exempt from program work requirements is to increase employment, 0.0375 percentage points. That the estimates show exempt women working more is somewhat of a surprise. At the least, however, the specifications control for unobserved state effects, year effects, age of children, and personal characteristics and yield no evidence that exempting broad categories of at-risk women from the work requirements decreases their employment.

\section{B. Identification}

Table VII contains additional specifications that relax some restrictions implicit in the indicator variables. For example, a state indicator will capture an average effect on employment of being in a state, but hold that constant over time. Similarly, the age of youngest child indicators will control for the employment effect of having a child a certain age, but hold that constant for all states. Also, the assumption that state policies and economic conditions (or age effects) had the same effect on everyone is relaxed. Such restrictions play a role in identification of the exempt coefficient. The exemption is defined by year, state, and child's age, and the analysis has controlled for each. Now, the three interactions of these more flexibly model differences between the exempt and not exempt. Using the notation from (1), consider the following specification:

$$
\begin{gathered}
Y_{i}=\beta_{0}+\beta_{1} \times \text { Exempt }_{i}+\beta_{2} \times X_{i}+\sum_{a=1}^{A} \sum_{s=1}^{S} \beta_{3, a, s} \times(\text { States }, i \times \text { Agea }, i)+\sum_{t=1}^{T-1} \beta_{4} \times \text { Yeart }_{t, i}+\mu_{i} ; \\
\text { where } \beta_{3, \mathrm{a}=1, \mathrm{~s}=1=0}
\end{gathered}
$$

Specification (2) shows the earlier specification (1), but with indicators for each child age-state pair in the data, except one omitted for identification. By interacting state and age of youngest child the analysis can control for the different effects state policies might have on the mother of a one year old as opposed to the mother of an infant. The analysis does not need to maintain that state policies affect the women with younger children and women with older

indicators. This test on the full set of interactions failed, however. The coefficient estimates do not indicate any change in conclusions. 
Table VII

\begin{tabular}{|c|c|c|c|c|}
\hline \multicolumn{5}{|c|}{ Marginal Effect Estimates } \\
\hline \multicolumn{5}{|c|}{ Dependent variable $=1$ if employed } \\
\hline Column: & 1 & 2 & 3 & 4 \\
\hline exempt: & 0.0375 & 0.0461 & 0.0405 & 0.0067 \\
\hline Std. Err. & $(0.019)$ & $(0.019)$ & $(0.020)$ & $(0.038)$ \\
\hline unemployment rate & -0.0189 & & -0.0195 & -0.0197 \\
\hline s.e. & $(0.012)$ & & $(0.012)$ & $(0.012)$ \\
\hline lagged unemployment rate & -0.0048 & & -0.0035 & -0.0013 \\
\hline s.e. & $(0.012)$ & & $(0.012)$ & $(0.012)$ \\
\hline Pseudo R-sq: & 0.1652 & 0.1767 & 0.1677 & 0.1923 \\
\hline L: & -6796.2 & -6698.0 & -6775.7 & -6523.3 \\
\hline child's age indicators: & yes & yes & no & no \\
\hline year indicators: & yes & no & no & yes \\
\hline state indicators: & yes & no & yes & no \\
\hline child's age - year pairs: & no & no & yes & no \\
\hline state-year pairs: & no & yes & no & no \\
\hline child's age - state pairs: & no & no & no & yes \\
\hline labor market characteristics: & yes & no & yes & yes \\
\hline personal characteristics: & yes & yes & yes & yes \\
\hline \multicolumn{5}{|c|}{$\begin{array}{l}\text { Sample is composed of the } 13,278 \text { single mothers living in states where TANF plans had been } \\
\text { implemented. Coefficients reported are marginal effects, or the change in the probability of } \\
\text { employment if the exemption status changed from being exempt to not exempt from program } \\
\text { work requirements. Robust standard errors in parentheses are corrected for duplicate } \\
\text { interviews for some households. }\end{array}$} \\
\hline
\end{tabular}


children in the same way. The policy coefficient is then identified by post-TANF changes within a given state, over time, and variation in the triple, age $\times$ state $\times y e a r$.

Table VII shows the results from several specifications, based on (2). In Column 1 are the results of (1) as shown in column 7 of Table VI. This specification includes labor market controls, personal characteristics (including mother's age), and dummies for child's age, year, and state. As noted above, the coefficient estimate is 0.0375 . Column 2 shows that specification, but with state and year indicators interacted. The labor market variables are removed for identification. These interactions allow the state effects to vary by year. The estimate increases to 0.0461. Column 3 includes child's age-year interaction dummies instead of child's age indicators and year indicators. The labor market variables are returned to capture state employment conditions in each year. The year*age interactions will control for unobserved aggregate changes in employment over time, while allowing those changes to be different for each child's age. For example, this allows the response to the business cycle, from 1997 to 2001, to differ by child's age. This coefficient estimate, shown in Column 3 of Table VII, is 0.0405 .

Child's age-state pair indicators are included in Column 4 (which estimates (2)) in place of child's age dummies and state dummies. This will capture state-specific effects that differ at each youngest child's age. In general, mother's employment rises with child's age, but the rate at which it does so may differ across states. Earlier, complications like exemption cutoffs not on the full year were discussed, which would be captured by state-child's age indicators that modeled the unobserved effect in each state under TANF of having a child a specific age. Any unobserved differential treatment across states that affects women differently according to the age of their youngest children, outside the exemption, would be absorbed by these indicators. For example, these unobservables could include targeted child care policies one state might direct towards women with children a certain age. Because of the variation in the exemption, this kind of state-specific policy can be controlled for, allowing the employment behavior of the exempt outside of the state*age interaction to identify its effect. Including these indicators reduces the estimated marginal effect to 0.0067 , with the estimate not statistically different from zero at any conventional level of significance.

If the estimates and range of the confidence intervals are considered, the effect of the work requirements would be small relative to the macroeconomic employment trends. For example, the coefficient estimate of 0.0375 in column 7 of Table VI that controls for state, year, 
and age, has a $95 \%$ confidence interval that spans from -0.005 to 0.075 , and the estimate from (2) of 0.0067 has a standard error of 0.038 and a confidence interval from -0.068 to 0.082 . In 1994, more than $40 \%$ of the single mothers received welfare, clearly an at-risk group likely to be affected by the policies. The group's employment rose more than $25 \%$ in a 5 -year period. Variation in the exemption, which represents variation in the application of program work requirements, should capture an employment effect if one exists. Neither the sample statistics, the trends, the comparison to married mothers, or the regression estimates indicate the exempt had lower employment rates than the not exempt following TANF's implementation.

\section{$\underline{\text { V. C. Related Issues }}$}

There are a few additional issues to note. Once the state-age interactions are included the results are robust, either to excluding other child's ages or to the inclusion or exclusion of any variables in the vector of personal characteristics. Analysis examining the relationship between employment and the exemption using different child ages shows that, conditional on the covariates, the exemption is negatively related to employment only for single mothers of newborns. The coefficient estimate in equation (2) is 0.0067 , but becomes 0.0088 if only mothers of children under age 8 are included. It becomes negative for a sample of mothers under 5 , with an estimate of -0.0030 , still indistinguishable from zero. For ages other than newborns the exemption is positively related to employment, and with mothers of newborns the sample size is too small to conclude the effect is significantly less than zero. Also, estimating the effect of the exemption in different years shows the only year in which the exemption appeared to have a significant negative effect was in March of 1996, prior to TANF. There was also a negative effect for 2001 (about a 2\% reduction in employment), but this was not significantly different from zero. Analysis of the estimates' sensitivity to the inclusion of individual variables produced estimates close to zero once child's age was flexibly modeled. One exception is when all the personal characteristics are dropped from (2), the marginal effect rises to over 0.02 .

Figure III showed that between 1996 and 1999 employment of exempt single mothers rose as much as the not exempt. ${ }^{26}$ To exploit a longer time series, estimates the exemption's

26. This is not surprising given that the exempt single mothers with young children had very low levels of employment in 1993 and 1994. Age-year interactions were included in specifications using longer time periods to account for exactly that. Interactions between the exempt indicator and unemployment rates were used to account 
Table VIII

\begin{tabular}{|c|c|c|c|}
\hline \multicolumn{4}{|c|}{ Anticipation of TANF's Work Requirements } \\
\hline & Single Mothers & Married Mothers & \\
\hline \multicolumn{2}{|l|}{ Exempt: Child Age $<1$} & & Difference: \\
\hline \multirow[t]{2}{*}{ Work required next year: } & 52.38 & 52.25 & -0.13 \\
\hline & (1.959) & $(0.968)$ & $(2.184)$ \\
\hline \multirow[t]{2}{*}{ Work required in 2 years: } & 60.66 & 59.85 & -0.81 \\
\hline & $(6.307)$ & $(3.052)$ & $(6.994)$ \\
\hline \multirow[t]{2}{*}{ Work required in $2+$ years: } & 51.22 & 56.60 & 5.38 \\
\hline & $(3.187)$ & (1.568) & $(3.509)$ \\
\hline \multicolumn{4}{|l|}{ Exempt: Child Age 1} \\
\hline \multirow[t]{2}{*}{ Work required next year: } & 57.14 & 59.04 & 1.89 \\
\hline & $(5.677)$ & (3.123) & $(6.442)$ \\
\hline \multirow[t]{2}{*}{ Work required in 2 or $2+$ years: } & 54.86 & 53.83 & -1.02 \\
\hline & (3.773) & $(1.974)$ & $(4.681)$ \\
\hline \multicolumn{4}{|c|}{$\begin{array}{l}\text { The purpose of comparing the single mothers employment rates, broken down by duration of time until } \\
\text { required work, is to test for advance response or anticipation that might be increasing employment among } \\
\text { exempt. Single mothers more than } 2 \text { years from required work have similar employment rates. The } \\
\text { purpose of comparing the Married Mothers is to see how local labor markets might contribute to those } \\
\text { differences or a lack of difference. Married mothers are very unlikely to have been affected by welfare } \\
\text { policy. Standard errors are in parentheses. }\end{array}$} \\
\hline
\end{tabular}


effect using data from 1993-2001 are shown in the Appendix, Table IX, which compares JOBS and waivers. Even controlling for differences in the response to the business cycle for mothers of children of different ages, the exemption appears to have implied some negative effect on employment only under JOBS and waivers, but not TANF. During the second half of the decade, as employment conditions improved, the exemption had no estimated effect on employment. ${ }^{27}$ One interpretation of this is that the work requirements are more useful when work is less appealing. The more attractive work is, the less policies designed to counteract the disincentives in welfare programs will matter. In other words, as the gap in utility between the choices of employment and non-employment narrows, policies designed to close that gap will be harder to identify since there is less utility difference that policy can affect. This interpretation also suggests a comprehensive understanding of welfare reform will remain until after observing the policies in different labor market conditions.

To explore whether the exemption may affect a subcategory of single mothers likely to enter welfare, the sample was broken into education categories. The specifications were estimated on the following groups: less than four years of high school, completed high school, and completed college. The results are shown in Columns 6, 7, and 8 of Appendix I. On college graduates who are very unlikely to be on welfare, the exemption implies a near zero effect on employment. The estimated employment effect of the exemption for both the groups of high school graduates and the dropouts is positive and similar to the estimates in Table VI.

Another question to address is whether the high levels of employment among the exempt might be in anticipation of work requirements. Simple comparisons are shown in Table VIII. The employment rates of women who will be required to work one year in the future are compared to those who will remain exempt longer. No significant pattern of advance response emerges. In the table, employment rates of single mothers within a year of required work are compared to the employment rates of single mothers two or more years away from required

for potentially more elastic labor supply among women with younger children; these interactions made the estimated effect of the exemption slightly more positive.

27. Also interesting is that under TANF welfare participation is not correlated with the exemption from work requirements. While this was first estimated to be the case in the CEA reports [CEA, 1997, 1999], similar results using the CPS sample are shown in appendix I, Table IX, columns 3, 4, and 5. This would be expected if there were no estimated effect on employment either. The implication is that those single mothers who are participating in welfare would participate regardless of the work requirements, and those who remain off welfare and employed would do so regardless of the work requirements. 
FIGURE IV

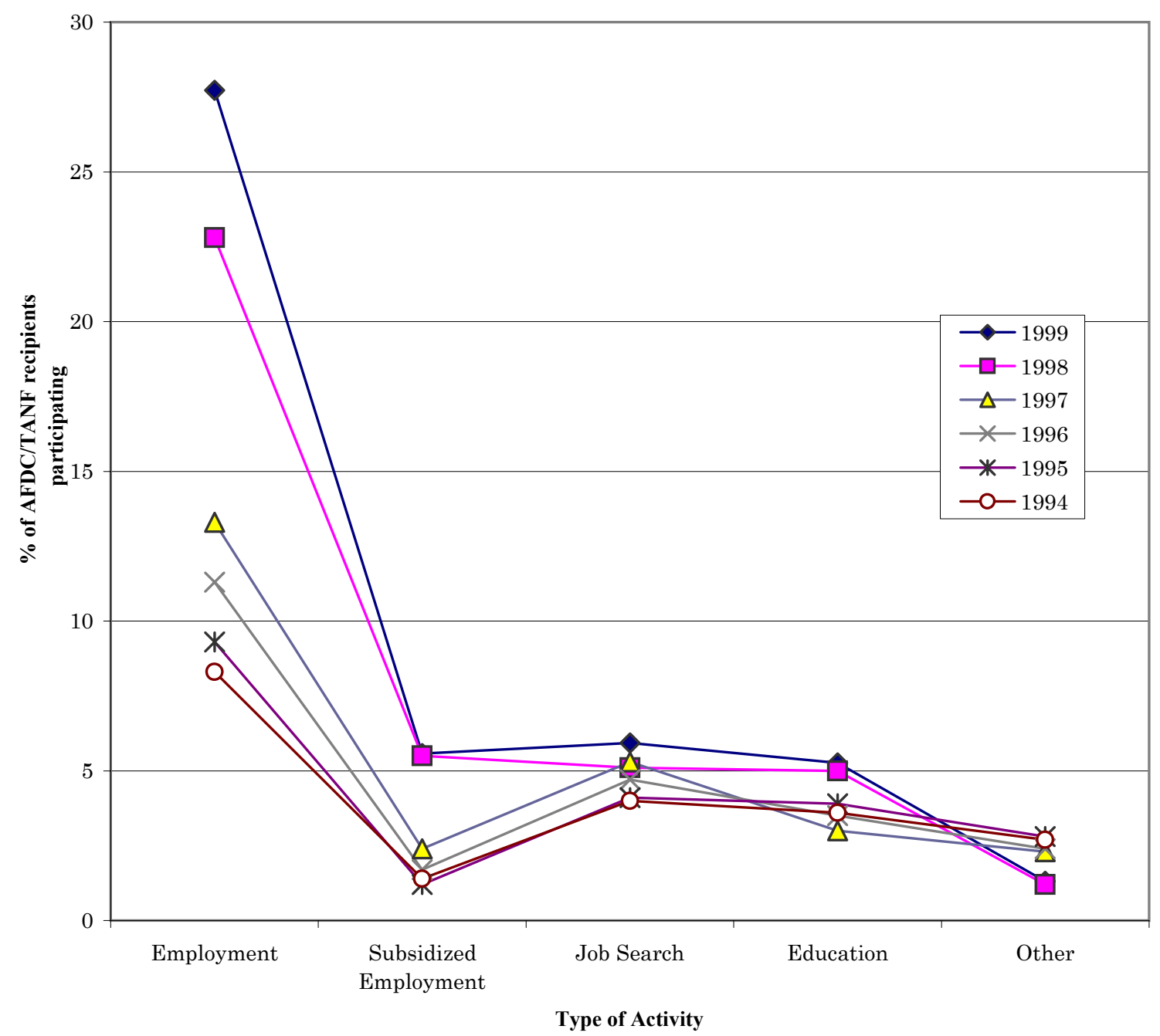

Figure IV

Distribution of Recipient Activities

(Note: adult recipients numbered 4,615,000 in 1994 and 2,112,000 in 1999.

Source: Ways and Means Green Book and U.S. ACF) 
work. Married women's employment is shown for perspective. There does not appear to be an anticipatory response among exempt women who are nearer to required work and activity participation. As another ad-hoc test of anticipation effects, the relationship between the exempt and their state's sanction severity was examined, because the more severe the penalty the more likely women may work ahead of their requirement, (or sanction severity might be an indicator of enforcement). However, interactions between states' sanction severity and the exempt indicator failed to uncover any significant correlation. ${ }^{28}$

\section{$\underline{\text { V. D. Discussion }}$}

TANF's work requirements represent a major policy shift, and certainly employment rates of single mothers rose during the period of reform. Another potential reason for this is the change in welfare programs" "culture," which caseworkers say was brought about by TANF, and to some extent the work requirements. For example, Hagen and Owens-Manley [2002] describe caseworkers happy to tell recipients to find jobs because before TANF that was not appropriate. However, changing a group's attitude is different from legally requiring activity participation, and likely could have been done without a specific level of work requirement. Alternatively, Cohen [2001] asked: if the work requirements are so successful, why are so few welfare recipients working? Figure IV shows the changes in recipient activity participation from 1994 through 1999. Slightly more recipients are in educational activities under TANF, and more are working. Even with the increases however, fewer than $30 \%$ of recipients were in unsubsidized employment as late as 1999, calling into question the enforcement and effectiveness of the higher levels of required participation. ${ }^{29}$ Under TANF, the states relied in part on credit for caseload reduction to meet the federal mandate. Without that credit, with 1999 employment

28. Also, the sample is conditional on being a single mother, and thus self-selected. For example, if women with low tastes for work were seeking to be exempt and on welfare, and thus having children, the estimated effect of the exemption would be an over estimate of the true effect, i.e. the true reduction in employment due to the exemption would have been even less. Alternatively, not-exempt women with high tastes for work, and thus likely to be working, might be getting married, and thus selecting themselves out of the sample. However, intuitively, the impact of selection is likely to be small. According to the Census Bureau, in 1993, 21.73\% of families with children under 18 were mother only families, compared to $21.88 \%$ in 2000 . While the proportion of single mother families is unchanged, there is evidence of only moderate responses in household structure to the reforms. Shoeni and Blank [2000] estimated small effects on the probability of female household headship due to waivers and TANF, between a $1.7 \%$ and $2.2 \%$ reduction [see also Ribar and Fitzgerald [2001] who find only limited links between policy and headship). It is unlikely that these changes would affect exempt and not exempt mothers very differently. 


\section{FIGURE V}

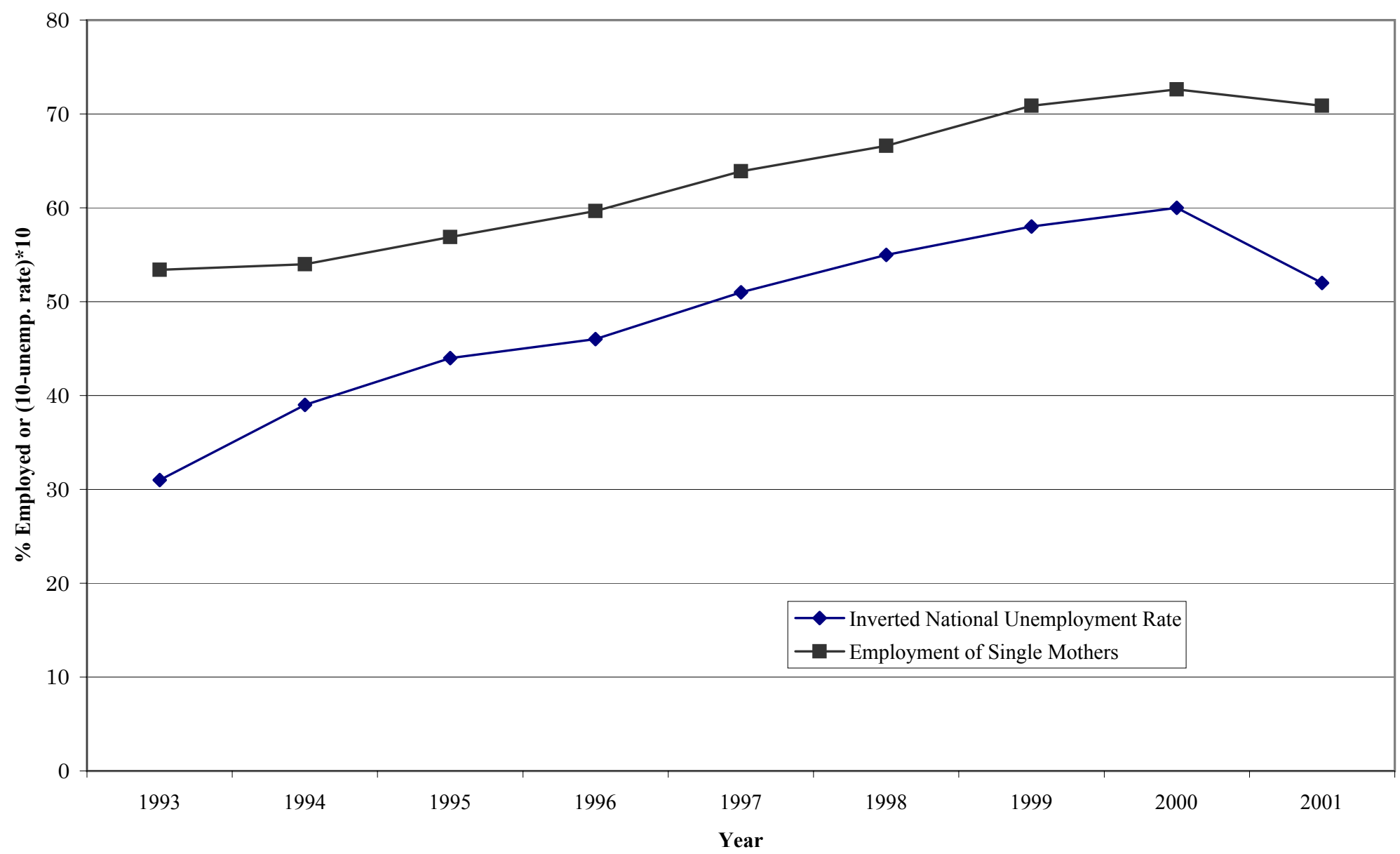

Figure $\mathrm{V}$

Comparing Single Mothers' Employment to the Unemployment Rate

(Note: The unemployment rate trend is inverted for comparison.) 
rates, many states would be far short of the proposed $70 \%$ of recipients needed to be in work activities, and face funding penalties.

Overall, the employment trend follows the business cycle more than it jumps at the implementation of TANF or waivers. The estimates note a percentage point decline in a state unemployment rate implies single mothers' employment rises 2 percentage points. Also, the employment growth variable implies each 1\% increase in the overall employment growth for a state corresponds to a unit increase in percent of single mothers employed. Thus, labor market conditions alone explain much of the employment changes. Some areas of the country saw unemployment rates fall 5 or more percentage points since 1993. Finding that a strong labor market increased employment is not surprising, as other research notes. As shown in Figure V, trends in the national annual unemployment rate (shown upside-down for perspective) and the employment rate of single mothers are mirror images of each other.

\section{CONCLUSION}

The evidence in this paper suggests that exempting single mothers from TANF's work requirements made no impact on the probability they were employed. Certainly other components of TANF could have been a strong influence. However, based on the strong employment increases among exempt women, the results imply that the increased work requirements were not the cause of the sustained increase in employment among single mothers. Instead, the results indicate that substantially more women could have been exempted from TANF's work requirements without affecting employment rates, or the employment growth during the 1990s. Those single mothers who went to work following welfare reform likely would have done so whether required to or not. 
APPENDIX I

Table IX

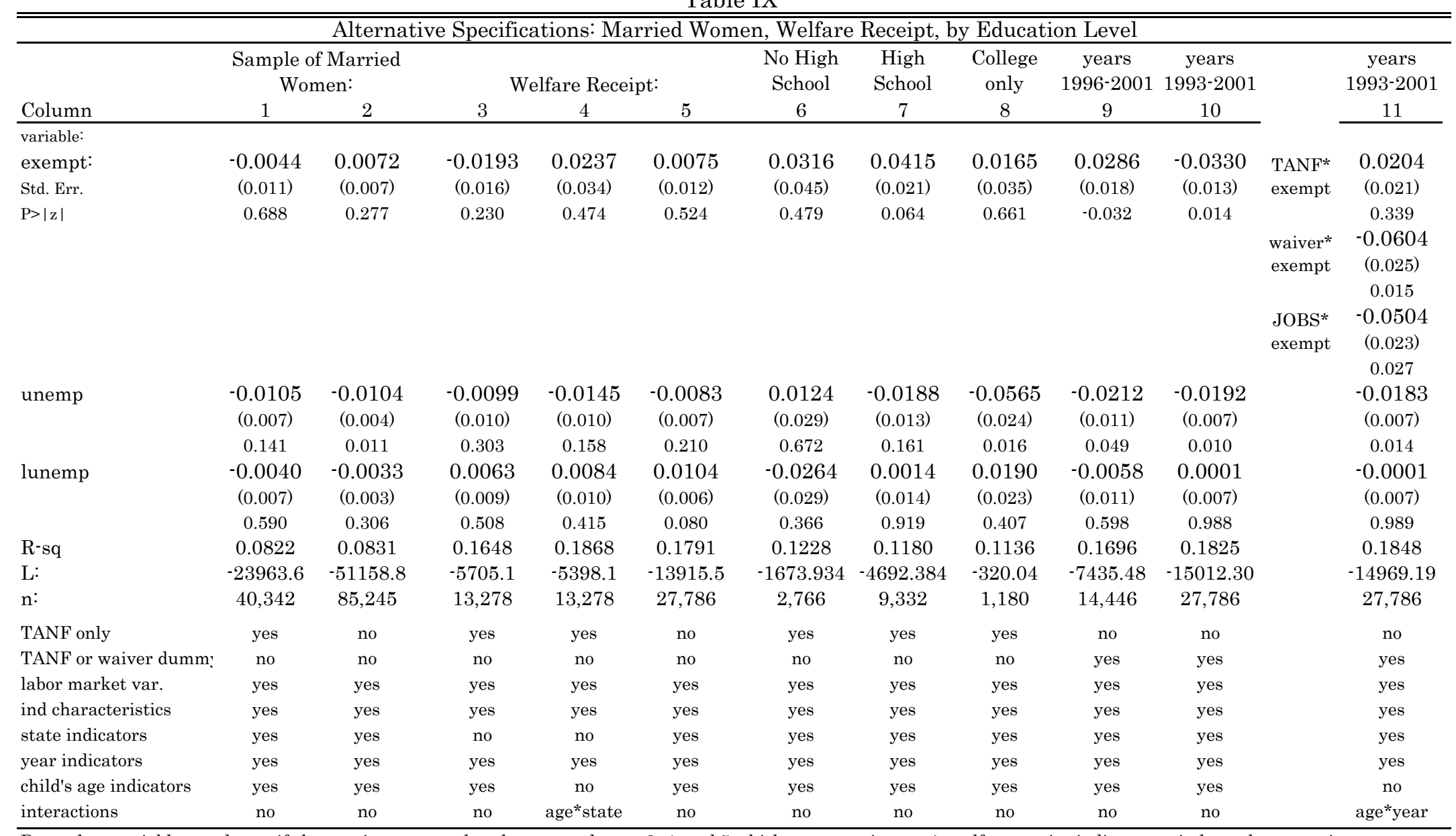

Dependent variable equals one if observation was employed, except columns 3,4 , and 5 which regress prior year's welfare receipt indicator on independent covariates.

Coefficients reported are marginal effects. Standard errors were adjusted due to duplicate interviews for some households. Columns $6,7,8$ separate education levels to

explore potential heterogeneity. Columns 1 and 2 use a sample of married women. Columns 9, 10, and 11 use 1993-2001 data to explore the effect under different policy regimes, and using more time variation in the age cutoffs. 


\section{APPENDIX I}

Additional specifications, for comparison, are shown in Table IX.

\section{APPENDIX II}

Two assumptions deserve more discussion. The estimates in the first column below, in Table X, show the results of specification (2) (which includes age*state interactions) from Table VII. The estimates in columns 2 and 3 reclassify women in states and periods under TANF where the exemption was not assigned by a whole year, but rather months like 18 months. In the CPS only age is observed. For those periods in those states where the exemption is 18 months (Virginia and Vermont) the analysis in the paper classified mothers of one year olds as not exempt. This affected 33 person-year observations. Column 2 below shows the estimates, based on specification (2) in the paper (with age*state interactions) under the alternative assumption that these women are exempt. In the paper they are assumed not exempt, to avoid having cases required to work classified as exempt. With so few affected cases, the results are unchanged.

Column 3, below, then reclassifies single mothers of newborns, where the exemption is only 3 months, as exempt. The estimate increases the effect of the exemption. This is not surprising. As noted in the paper, the only age for which there is a correlation between being exempt and lower employment, is for single mothers of newborns. However, all single mothers of newborns have some family leave available following birth so the analysis in paper assumed these women with only 3 month exemptions were not exempt. Presumably any employment effects specific to having a newborn, or a newborn in a specific state would be captured by the corresponding indicator variable.

Next, the control group may contain some single mothers who may be unable to take the exemption. This would be because they used the exemption already. Some states placed restrictions on the number of times the exemption can be utilized after 1997. The restrictions are recent, and several states' restrictions are merely a guideline where, for example, caseworkers are allowed to offer the exemption on a case by case basis if it has already been utilized.

Presumably, it would have been difficult for a single mother to have had enough pregnancies and children for this to have much affect between 1997 and 2001. Also, draft proposals to revise the federal legislation had removed the restrictions on counting repeated uses of the exemption in the states' participation rate calculations. In all there are 209 women in the exempt group who are 
classified as exempt, but who have more than one child, and live in a state, in a period, where utilization of the exemption may be restricted. Their behavior is examined in column 4, below.

The conditional employment levels of these "potentially not exempt" are nearly identical to the other women in the exempt category, and the results of the analysis are not sensitive to the empirical treatment of these individuals. Even as a potential comparison group of their own, their behavior varies little from the other women classified as exempt. The 209 potentially restricted women have an employment rate of $48.8 \%$, while the other exempt women with multiple children have a 50.6\% employment rate. In 1997, five states had such exemption use restrictions. By 2000, 18 states had a potential restriction, however, several of those did allow repeated exemptions, left to county or caseworker discretion.

Table X

\begin{tabular}{|c|c|c|c|c|}
\hline \multicolumn{5}{|c|}{ Alternate Assignment of Exemption } \\
\hline column: & $(2)$ & 2 & 3 & 4 \\
\hline \multicolumn{5}{|l|}{ variable: } \\
\hline exempt & 0.0067 & 0.0067 & 0.0195 & 0.0067 \\
\hline Std. Er. & $(0.038)$ & $(0.038)$ & $(0.040)$ & $(0.039)$ \\
\hline $\mathrm{P}>|\mathrm{z}|$ & 0.862 & 0.862 & 0.626 & 0.863 \\
\hline \multirow[t]{3}{*}{ Pot. Not Exempt } & & & & 0.0019 \\
\hline & & & & $(0.045)$ \\
\hline & & & & 0.967 \\
\hline \multirow[t]{3}{*}{ unemp } & -0.0197 & -0.0197 & -0.0196 & -0.0197 \\
\hline & $(0.012)$ & $(0.012)$ & $(0.012)$ & $(0.012)$ \\
\hline & 0.109 & 0.109 & 0.110 & 0.109 \\
\hline \multirow[t]{3}{*}{ lunemp } & -0.0013 & -0.0013 & -0.0017 & -0.0013 \\
\hline & $(0.012)$ & $(0.012)$ & $(0.012)$ & $(0.012)$ \\
\hline & 0.915 & 0.915 & 0.893 & 0.915 \\
\hline R-sq & 0.1923 & 0.1923 & 0.1923 & 0.1923 \\
\hline L: & -6523.3 & -6523.3 & -6523.2 & -6523.3 \\
\hline \multicolumn{5}{|c|}{$\begin{array}{l}\text { Dependent variable equals one if single mother was employed. Adjusted } \\
\text { standard errors in parentheses. P }>|\mathrm{z}| \text { represents the significance level of a } \\
\text { simple test of whether coefficient is different from zero. Specifications } \\
\text { include full set of individual characteristics and state*age interactions as in } \\
\text { specification (2) in Table VII in the paper and column } 1 \text { above. }\end{array}$} \\
\hline
\end{tabular}




\section{REFERENCES}

Administration for Children and Families. "Temporary Assistance for Needy Families Program (TANF), Fourth Annual Report to Congress," Office of Planning, Research and Evaluation, April, 2002.

Available at ww.acf.dhhs.gov/programs/opre/ar2001/indexar.html

Anderson, Steven G. (2002). "Ensuring the Stability of Welfare-to-Work Exits: The Importance of Recipient Knowledge about Work Incentives," Social Work, 47(2): 162-170, April.

Baum, Charles L. (2002). "The Effects of Maternity Leave Legislation On Mothers' Labor Supply After Childbirth," Southern Economic Journal, forthcoming.

Bell, Stephen H. (2001). "Why Are Welfare Caseloads Falling?” Discussion Paper, The Urban Institute, March.

Berlin, Gordon L. (2002). "What Works in Welfare Reform. Evidence and Lessons to Guide TANF Reauthorization," Manpower Demonstration Research Corporation. Report. Available at www.mdrc.org

Blank, Rebecca M., and Lucie Schmidt (2001). "Work, Wages, and Welfare," in The New World of Welfare, ed. Rebecca M. Blank and Ron Haskins, Brookings Institution Press, Washington, D.C.

Blank, Rebecca M., David Card and Philip K. Robins (1999). "Financial Incentives for Increasing Work and Income Among Low-Income Families," National Bureau of Research Working Paper No. 6998, March.

Burtless, Gary, and Daniel Friedlander (1995). Five years after: The long-term effects of welfare-to-work programs. Russell Sage Foundation. New York. 1995

Cherlin, Andrew, and Pamela Winston, Ronald Angel, Linda Burton, P. Lindsay Chase-Lansdale, Robert Moffitt, William Julius Wilson, Rebekah Levine Coley and James Quane (2002). "What welfare recipients know about the new rules and what they have to say about them," Policy Brief 00-1, Welfare, Children \& Families: A Three City Study, Johns Hopkins University.

Cohen, Marie (2001). " Mandatory Work-Related Activities for Welfare Recipients: The Next Step in Welfare Reform," Welfare Reform Academy Working Paper No. 1, Maryland School of Public Affairs, October.

Committee on Ways and Means (1994, 1996, 1998, 2000). The Green Book: Overview of Entitlement Programs, Background Material and Data on Programs Within the Jurisdiction of the Committee on Ways and Means U.S. House of Representatives. Committee on Ways and Means, U.S. House of Representatives. 14th through 17th editions. Available on-line at http://aspe.os.dhhs.gov/2000gb/

Council of Economic Advisors (1997). "Technical Report: Explaining the Decline in Welfare Receipt, 1993-1996,"A Report by the Council of Economic Advisors, May.

Council of Economic Advisors (1999). "Technical Report: The Effects of Welfare Policy and the Economic Expansion on Welfare Caseloads: An Update," A Report by the Council of Economic Advisors, August.

Crouse, Gil, (1999). "State Implementation of Major Changes to Welfare Policies, 1992-1998," Manuscript, Office of Human Services Policy, Assistant Secretary for Planning and Evaluation, U.S. Department of Health and Human Services.

Currie, Janet, and Jeffrey Grogger, (2001). "Explaining Recent Declines in Food Stamp Program Participation," Brookings-Wharton Papers on Urban Affairs, 0(0): 203-229.

Department of Health and Human Services (1997). "Setting the Baseline: A Report on State Welfare Waivers," Department of Health and Human Services Office of the Assistant Secretary for Planning and Evaluation, June.

Department of Health and Human Services (1998). "Aid to Families with Dependent Children, The Baseline," Department of Health and Human Services Office of the Assistant Secretary for Planning and Evaluation, June.

Dickert-Conlin, Stacy, Douglas Holtz-Eakin (2000). "Employee-Based Versus Employer-Based Subsidies to Low-Wage Workers: A Public Finance Perspective," in Economic Conditions and Welfare 
Reform, Sheldon H. Danziger, ed., Kalamazoo, Michigan: W.E. Upjohn Institute for Employment Research.

Ellwood, David T., and Elisabeth D. Welty (2000). "Public Service Employment and Mandatory Work: A Policy Whose Time Has and Gone and Come Again?" in Economic Conditions and Welfare Reform, Sheldon H. Danziger, ed., Kalamazoo, Michigan: W.E. Upjohn Institute for Employment Research.

Figlio, David, and James P. Ziliak (1999). "Welfare Reform, the Business Cycle, and the Decline in AFDC Caseloads," in Economic Conditions and Welfare Reform, Sheldon H. Danziger, ed., Kalamazoo, Michigan: W.E. Upjohn Institute for Employment Research.

Fitzgerald, John M., and David C. Ribar (2001). "The Impact of Welfare Waivers on Female Headship Decisions," manuscript, November.

Fraker, Thomas M., Lucia Nixon, Jonathan Jacobson, Anne Gordon, and Thomas Martin (1998). “Iowa's Family Investment Program: Two-Year Impacts,” Mathematica Policy Research, Inc., Report submitted to Iowa Department of Human Services, December.

Grogger, Jeffrey (2001). "The Effects of Time Limits and Other Policy Changes on Welfare Use, Work, and Income Among Female-Headed Families," National Bureau of Economic Research Working Paper No. 8153, March.

Grogger, Jeffrey (2003). "Welfare Transitions in the 1990s: The Economy, Welfare Policy, and the EITC," manuscript, January.

Grogger, Jeff and Stephen G. Bronars, (2001). "The Effect of Welfare Payments on the Marriage and Fertility Behavior of Unwed Mothers: Results from a Twins Experiment," Journal of Political Economy, 109(3):529-545.

Grogger, Jeffrey, Charles Michalopoulos (1999). "Welfare Dynamics Under Term Limits," National Bureau of Economic Research Working Paper No. 7353, September.

Grogger, Jeffrey, Charles Michalopoulos (2003). "Welfare Dynamics Under Term Limits," Journal of Political Economy, 3(111), June.

Hahn, Jinyong, Petra Todd, and Wilbert Van der Klaauw (1999). "Evaluating the Effect of an Antidiscrimination Law Using A Regression Discontinuity Design," National Bureau of Economic Research, Working Paper 7131, May.

Hahn, Jinyong, Petra Todd, and Wilbert Van der Klaauw (2001). "Identification and Estimation of Treatment Effects with a Regression Discontinuity Design," Econometrica. 69(1):20109, January.

Holzer, Harry J. (2002). "Employers and welfare recipients: What their interactions imply for public policy," Focus, University of Wisconsin-Madison, 22(1): 71-75.

Hotz, V. Joseph, Guido W. Imbens, and Jacob A. Klerman (2001). "The Long Term Gains from GAIN: A Re-Analysis of the Impacts of the California GAIN Program," manuscript. September.

Kaestner, Robert, and Neeraj Kaushal (2001). "Immigrant and Native Responses to Welfare Reform," National Bureau of Economic Research Working Paper No. 8541, October.

Karoly, Lynn A. (2001). "Estimating the Effect of Work Requirements on Welfare Recipients: A Synthesis of the National Literature," Testimony, Subcommittee on 21 st Century Competitiveness, Committee on Education and the Workforce, U.S. House of Representatives, October 16.

Keane, Michael and Robert Moffitt (1998). "A Structural Model of Multiple Welfare Program Participation and Labor Supply," International Economic Review 39 (3), August: 553-589.

Klerman, Jacob, and Steven Haider (2000). "A Stock-flow Analysis of the Welfare Caseload: Insights from California Economic Conditions," Unpublished Working Paper, RAND, September.

Knab, Jean Tansey, and Johannes Bos, Daniel Friedlander, and Joanna Weissman (2000). "Do Mandates Matter? The Effects of a Mandate to Enter a Welfare-to-Work Program," unpublished manuscript, November.

Levine, Philip B., Diane M. Whitmore (1998) "The Impact of Welfare Reform on the AFDC Caseload," National Tax Association Proceedings, Ninetieth Annual Conference on Taxation: 24-33.

London, Rebecca A. (1998). 'Trends in Single Mothers' Living Arrangments from 1970 to 1995: 
Correcting the Current Population Survey," Demography 35(1): February, 125-131.

Meyer, Bruce D. (2002). "Labor Supply at the Extensive and Intensive Margins: The EITC, Welfare, and Hours Worked," The American Economic Review, Papers and Proceedings of the 114th Annual Meeting of the American Economics Association, (92)2, May

Meyer, Bruce D. James X. Sullivan (2001). "The Effects of Welfare and Tax Reform: The Material WellBeing of Single Mothers in the 1980s and 1990s," National Bureau of Economic Research Working Paper No. 8298, May.

Meyer, Bruce D., Dan T. Rosenbaum (1999). “Welfare, the Earned Income Tax Credit, and the Labor Supply of Single Mothers,” National Bureau of Economic Research Working Paper No. 7363, September.

Moffitt, Robert A. (1999). "The Effect of Pre-PRWORA Waivers on AFDC Caseloads and Female Earnings, Income and Labor Force Behavior," in Economic Conditions and Welfare Reform, Sheldon H. Danziger, ed., Kalamazoo, Michigan: W.E. Upjohn Institute for Employment Research.

North Carolina Department of Health and Human Services, Division of Social Services (1999). North Carolina's Temporary Assistance for Needy Families State Plan , P.L. 104-193, July.

Ribar, David C. (2002). "Transitions From Welfare and the Employment Prospects of Low-skill Workers," manuscript, July.

Schoeni, Robert F., Rebecca M. Blank (2000). "What Has Welfare Reform Accomplished? Impacts on Welfare Participation, Employment, Income, Poverty, and Family Structure," RAND Labor and Population Program Working Paper Series 00-02, March.

State Policy Documentation Project, http://www.spdp.org, a joint project of The Center on Budget and Policy Priorities and the Center for Law and Social Policy.

U.S. Department of Health and Human Services (1997). "Setting the Baseline: A Report on State Welfare Waivers," Department of Health and Human Services Office of the Assistant Secretary for Planning and Evaluation, June.

U.S. Department of Health and Human Services (1998). "Aid to Families with Dependent Children, The Baseline," Department of Health and Human Services Office of the Assistant Secretary for Planning and Evaluation, June.

U.S. Department of Health and Human Services Administration for Children and Families Office of the Assistant Secretary for Planning and Evaluation (2000). "Executive Summary: National Evaluation of Welfare-to-Work Strategies. What Works Best for Whom: Impacts of 20 Welfare-to-Work Programs by Subgroup," Manuscript, Manpower Demonstration Research Corporation, August.

U.S. Department of Health and Human Services Administration for Children and Families Office of the Assistant Secretary for Planning and Evaluation (2001). "Executive Summary: National Evaluation of Welfare-to-Work Strategies. How Effective Are Different Welfare-to-Work Approaches? FiveYear Adult and Child Impacts for Eleven Programs," Manuscript, Manpower Demonstration Research Corporation, November.

Urban Institute, Welfare Rules Database, available at www.urban.org.

van der Klaauw, Wilbert, (2002). "Estimating the Effect of Financial Aid Offers on College Enrollment: A Regression-Discontinuity Approach," International Economic Review, (forthcoming).

Wallace, Geoffrey, Rebecca M. Blank (1999). "What Goes Up Must Come Down? Explaining Recent Changes in Public Assistance Caseloads," in Economic Conditions and Welfare Reform, Sheldon H. Danziger, ed., Kalamazoo, Michigan: W.E. Upjohn Institute for Employment Research.

Zedlowski, Sheila R. (1999). "Work-Related Activities and Limitations of Current Welfare Recipients," Discussion Paper, The Urban Institute, July.

Ziliak, James P., David N. Figlio, Elizabeth E. Davis and Laura S. Connolly (2000) "Accounting for the Decline in AFDC Caseloads, Welfare Reform or the Economy?" The Journal of Human Resources 35 (3), Summer:570-586. 